$A D-A 104032$

$A D / 1 / 10+032$

TECHNICAL REPORT ARBRL-TR-02344

CALCULATION OF BLOWOUT GUN

NOZZLE TEMPERATURES

Charles S. Smith

J. Richard Ward

July 1981

US ARMY ARMAMENT RESEARCH AND DEVELOPMENT COMMAND
BALLISTIC RESEARCH LABORATORY
ABERDEEN PROVING GROUND, MARYLAND

Approved for public release; distribution unlimited. 
Destroy this report when it is no longer needed. Do not return it to the originator.

Secondary distribution of this report by originating or sponsoring activity is prohibited.

Additional copies of this report may be obtained from the National Technical Information Service, U.S. Department of Commerce, Springfield, Virginia 22161 .

The findings in this report are not to be construed as an official Department of the Army position, unless so designated by other authorized docunents. 


\begin{tabular}{|c|c|}
\hline REPORT DOCUMENTATION PAGE & $\begin{array}{c}\text { READ INSTRUCTIONS } \\
\text { BEFORE COMPLETING FORM }\end{array}$ \\
\hline \begin{tabular}{l|l|l|} 
1. REPORT NUMBER & 2. GOVT ACCESSION NO. \\
TECHNICAL REPORT ARBRL-TR-02344 &
\end{tabular} & 3. RECIPIENT'S CATALOG NUMBER \\
\hline \multirow[t]{2}{*}{$\begin{array}{l}\text { 4. TITLE (and Subtitio) } \\
\text { CALCULATION OF BLOWOUT GUN NOZZLE TEMPERATURES }\end{array}$} & $\begin{array}{l}\text { 5. TYPE OF REPORT \& PERIOD COVERED } \\
\text { BRL Technical Report }\end{array}$ \\
\hline & 6. PERFORMING ORG. REPORT NUMBER \\
\hline $\begin{array}{l}\text { 7. AUTHOR(o) } \\
\text { Charles S. Smith* } \\
\text { J. Richard Ward }\end{array}$ & 8. CONTRACT OR GRANT NUMBER(o) \\
\hline $\begin{array}{l}\text { 9. PERFORMING ORGANIZATION NAME AND ADORESS } \\
\text { US Army Armament Research \& Development Command } \\
\text { US Army Ballistic Research Laboratory } \\
\text { ATTN: DRDAR-BLI } \\
\text { Aberdeen Proving Ground. MD } 21005\end{array}$ & $\begin{array}{l}\text { 10. PROGRAMELEMENT, PROJECT, TASK } \\
\text { AREA \& WORK UNIT'NUMBERS } \\
1 \mathrm{~L} 162618 \text { AH } 80\end{array}$ \\
\hline $\begin{array}{l}\text { 11. CONTROLLING OFFICE NAME AND ADDRESS } \\
\text { US Army Armament Research \& Development Command } \\
\text { US Baliistic Research }\end{array}$ & $\begin{array}{l}\text { 12. REPORT DATE } \\
\text { JULY } 1981\end{array}$ \\
\hline $\begin{array}{l}\text { ATTN: DRDAR-BL } \\
\text { Aberdeen Proving Ground, MD } 21005\end{array}$ & $\begin{array}{l}\text { 13. NUMBER OF PAGES } \\
46\end{array}$ \\
\hline 14. MONITORING AGENCY NAME A ADDRESS(It difforent from Controlline Offlco) & $\begin{array}{l}\text { 15. SECURITY CLASS. (of thic roport) } \\
\text { UNCLASSIFIED }\end{array}$ \\
\hline . & $\begin{array}{l}\text { 15a. DECLASSIFICATION/DOWNGRADING } \\
\text { SCHEDULE }\end{array}$ \\
\hline
\end{tabular}

Approved for public release; distribution unlimited.

17. DISTRIBUTION STATEMENT (of the ebetract ontered in Block 20, If difforent from Roport)

18. SUPPLEMENTARY NOTES

*Naval Surface Weapons Center, Dahlgren Laboratory, Dahlgren, VA

19. KEY WORDS (Continue on rever we side If necessary and idontify by block number)

Gun Propellants

Gun wear and erosion

Calspan

$37 \mathrm{~mm}$ blowout gun

Bore surface temperature

Nordheim's method

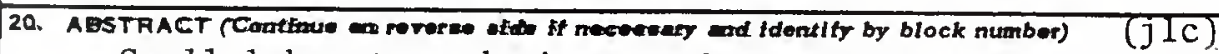

Small laboratory devices such as the $37 \mathrm{~mm}$ blowout gun at the BRL have a long history in unraveling the factors influencing gun barrel wear. Such devices are particularly useful when testing scarce and expensive experimental propellants. An unresolved question is whether relative propellant erosivity measured in such laboratory devices correlates with large-caliber gun wear.

(Continued on next pge) 


\section{ABSTRACT (Contd)}

To try to answer the question, Nordheim's scheme for computing heat transfer in guns and erosion yents was used to calculate bore surface temperatures in a $17.3 \mathrm{~mm}$ diameter nozzle for a series of five propellants for which the wear had already been measured. Empirical expressions for estimating wear in guns suggested the wear should increase exponentially with peak bore surface temperature if the nozzles mimicked wear in guns. A linear-least squares of natural $\log$ of wear vs. peak temperature showed the wear in nozzles could be fit to such an expression, specifically ln $\omega=-9.7+0.0094 \mathrm{~T}$, where $\mathrm{T}$ is the peak surface temperature in Kelvin and wear is expressed as $\mu /$ shot.

To test how well the dependence of wear on bore surface temperature compares to large caliber guns, bore surface temperatures computed by Calspan from heat input measurements in the $155 \mathrm{~m} \mathrm{M185}$ cannon were plotted against wear. The slope was $0.0076 \mathrm{~K}^{-1}$ suggesting the blowout gun wear may exaggerate relative wear expected in a large-caliber gun by ten percent. 
I. INTRODUCTION . . . . . . . . . . . . . . . . 7

II. INPUT PARAMETERS AND COMPUTER CODES . . . . . . . . 8

III. RESULTS AND DISCUSSION . . . . . . . . . . . 10

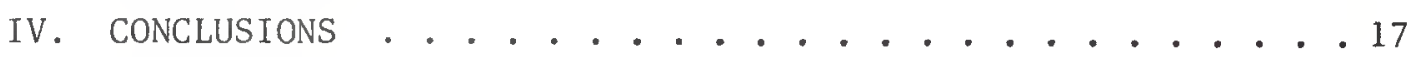

REFERENCES ..................... 21

APPENDIX ........................ 23

DISTRIBUTION LIST . . . . . . . . . . . 4 43 
1. Compositions and Grain Dimensions of M30 and HFP Propellants. 9

2. Compositions and Grain Dimensions of M5, M8, and M1 Propellants... . . . . . . . . . . . . . . . . . 9

3. Propellant Parameters . . . . . . . . . . . . 11

4. Experimental Data From Blowout Gun Experiments . . . . 12

5. Computed Heat Transfer Results . . . . . . . . . 13

6. Comparison Between Experimental Wear and Wear Computed With Equation (5) . . . . . . . . . . . . . 14

7. Bore Surface Temperatures and Wear for $155 \mathrm{~mm}$ Charges Without Additive . . . . . . . . . . . . . . . . 15

8. Calculated Heat Input and Surface Temperatures for $311 / 70$ and $37 \mathrm{~mm}$ Blowout Gun . . . . . . . . . . . . . . 17 


\section{INTRODUCTION}

Smal1 laboratory devices such as vented chambers or blowout guns have a long history in understanding gun barrel wear. ${ }^{1}$ Compared with large-caliber gun tests, such devices need less propellant, need less room for safe firing, and have inserts which can be removed for postfiring analysis. An unanswered question is how to relate wear in the devices with wear in large-caliber guns. A recent JANNAF workshop concluded that laboratory devices cannot evaluate wear-reducing additives, 2 and that test devices in three laboratories have given contradictory results with the same propellants.3,4

This report attempts to relate erosivity from propellants in the BRL $37 \mathrm{~mm}$ blowout gun to wear expected in large caliber guns. Empirical formulas 5,6 presume the wear is exponentially proportional to the maximum bore surface temperature. Bore surface temperatures in the empiracal models are estimated with interior ballistic parameters such as charge weight, flame temperature, gun diameter, and peak pressure.7,8

"Hypervelocity Guns and the Control of Gun Erosion," Summary Technical Report of Division 1, NDRC, Volume 1, Washington, DC 1946.

${ }^{2} J . A$. Lanion and J.R. Ward, "Workshop Report on Wear-Reducing Additives and Their Performance in Guns, "Proceedings of the 17th JANNAF Combustion Meeting, CPIA Publication 329, November 1980.

${ }^{3}$ A.J. Bracuti, L. Bottei, J.A. Iannon, and L.H. Caveny, "Evaluation of Propezlant Erosivity with Vented Chamber Apparatus," 1980 JANNAF Propulsion Meeting, CPIA Publication, 315, March 1980.

4 J.R. Ward, R.W. Geene, A. Niiler, A. Rye, and B.B. Grollman, "Blowout Gun Erosivity Experiments with Double-Base, Triple-Base, and Nitramine Propezlants, 1980 JANNAF Combustion Meeting CPIA Publication, 315, March 1980.

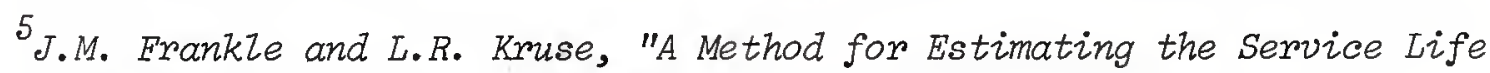
of a Gun or Howitzer," BRL Memorandum Report No. 1852, June 1967.

${ }^{6}$ C.S. Smith and J.S. O'Brasky, "A Procedure for Gun Barrel Life Estimation," Proceedings of the Tri-Service Gun Tube Wear and Erosion Symposium, ADPA, Dover, NJ, March 1977.

${ }^{7}$ J. Comer, Theory of the Interior Ballistics of Guns, John Wiley \& Sons, Inc., $N Y, 1950$.

${ }^{8}$ L.W. Nordheim, H. Soodak, and G. Nordheim, "Thermal Effects of Propellant Gases in Erosion Vents and Guns," NDRC Armor and Ordnance Report No. A-262, March 1944. 
This report uses Nordheim's scheme to compute the peak surface temperatures during wear tests of five propellants. 9 If the relative wear of the propellants in the blowout gun is the same as in large guns, then a plot of natural logarithm of wear vs peak temperature should be linear, with the slope identical to that in guns. Wear tests in Reference 9 incorporated Niiler's radioactive technique 10 to correlate mass loss and diameter change.

\section{INPUT PARAMETERS AND COMPUTER CODES}

Three computer codes were used to perform the calculations discussed in the report. The first program, IB $3 / 70$, computes interior ballistics data for guns. The second program, NOZZLE, computes interior ballistic data for a blowout gun with an erosion nozzle. The third program, NEWNSN, computes heat transfer using files of IB $3 / 70$ and NOZZLE. Listings for each program are contained in the Appendix.

The assumed heat input, as described fully in Reference 8, was taken to be

$$
Q=\frac{1}{2} \lambda C_{p} \rho U \Delta T,
$$

where $\mathrm{q}=$ heat flux, $\mathrm{J} / \mathrm{m}^{2} \cdot \mathrm{s}$,

$$
\begin{aligned}
\lambda & =\text { friction factor }, \\
C_{p} & =\text { specific heat, } \mathrm{J} / \mathrm{kg} \cdot \mathrm{K}, \\
\rho & =\text { propellant gas density, } \mathrm{kg} / \mathrm{m}^{3}, \\
\mathrm{U} & =\text { gas velocity, } \mathrm{m} / \mathrm{s}, \text { and } \\
\Delta \mathrm{T} & =\text { temperature difference between propellant gas and wall, } \mathrm{K} .
\end{aligned}
$$

Following Nordheim's method, a friction factor of $1 / 253$ was used for the $17.3 \mathrm{~mm}$ diameter nozzle.

Computations were done for the five propellants evaluated in Reference 9 . The compositions are 1 isted in Tables 1 and 2 .

9 R.W. Geene, J.R. Ward, T.L. Brosseau, A. Niiler, R. Birkmire, J.J. Rocchio, "Erosivity of a Nitramine Propelzant," BRL Technical Report No. 02094, August 1978. (AD \#A060590)

10 S.E. Caldwell ang A. Niizer, "The Measurement of Wear from Steel Using the Radioactive ${ }^{56}$," BRL Report No. 1923, September 1976. (AD \#A030262) 
TABLE 1. COMPOSITIONS AND GRAIN DIMENSIONS OF M30 AND HFP PROPELLANTS

M30

PPL-A-6372

Nitrocellulose $(12.6 \% \mathrm{~N})$

Nitroglycerin

Nitroguanidine

RDX

Dioctylphthalate

Ethyl Centralite

Cryolite

Total Volatiles (Residual)

Grain Length, mm

Grain Diameter, mm

Grain Perf. Diameter, mm

Grain Web, mm

Grain Geometry
$28.0 \%$

22.5

47.7

1.5

0.3

0.2

7.78

1.59

0.46

0.56

SP
HFP

PPL-A-6380

$29.3 \%$

22.7

5.0

36.5

5.0

1.5

0.3

10.58

2.37

0.77

0.80

SP

TABLE 2. COMPOSITIONS AND GRAIN DIMENSIONS OF M5, M8, AND M1 PROPELLANTS

$\begin{array}{lr}\text { Nitrocellulose }(13.25 \% \mathrm{~N}) & 81.95 \\ \text { Nitroglycerin } & 15.00 \\ \text { Ethyl Centralite } & 0.60 \\ \text { Barium Nitrate } & 1.40 \\ \text { Potassium Nitrate } & 0.75 \\ \text { Diethylphtalate } & \\ \text { Dinitrotoluene } & \\ \text { Dibutylphthalate } & \\ \text { Diphenylamine, Added } & 2.30 \\ \text { Ethyl Alcohol, Residual } & 0.70 \\ \text { Water, Residual } & 0.30 \\ \text { Graphite } & \\ \text { Grain Length, mm } & 10.58 \\ \text { Grain Diameter, mm } & 3.92 \\ \text { Grain Perf. Diameter, mm } & 0.41 \\ \text { Grain Web, mm } & 0.69 \\ \text { Grain Geometry } & 7 \text { Per }\end{array}$

0.70

0.30

M5
$81.95 \%$
15.00
0.60
1.40
0.75

10.58

3.92

0.41

0.69

7 Perf
M8

$52.15 \%$

43.00

0.60

1. 25

3.00

10.00

5.00

1.00

0.75

0.50

0.40

0.50

8.26

3.68

0.37

0.64

7 Perf 
Propellant parameters required for the computations are listed in Table 3 .

The term, $B / W$, is used to relate burning rate, $r$, with chamber pressure, $P$, and propellant web, $W$, by

$$
r=(P+44.8)\left(\frac{B}{W}\right) \cdot W
$$

Propellant webs are listed in Tables 1 and 2.

For the blowout gun, chamber volume and nozzle area were $315 \mathrm{~cm}^{3}$ and $2.36 \mathrm{~cm}^{2}$, respectively.

\section{RESULTS AND DISCUSSION}

The experimental results from Reference 9 are listed in Table 4.

Table 5 gives calculated time to maximum pressure, peak nozzle surface temperature, heat input, and time from nozzle rupture to peak nozzle surface temperature.

A Iinear least squares fit tested the exponential dependence of wear with peak surface temperature.

$$
\ln (w)=a+b T,
$$

where $\mathrm{w}=$ wear, $\mu /$ shot,

$\mathrm{T}=$ peak bore surface temperature, $\mathrm{K}$, and

$$
\mathrm{a}, \mathrm{b}=\text { constants. }
$$

The best fit values of $a$ and $b$ were $-9.7 \pm 2$ and $0.0094 \pm 0.002$, respectively, with error representing one standard deviation. Table 6
compares experimental wear and wear computed with Eq. (3). Eq. (3) clearly underestimates wear for M1 with a peak temperature of $773 \mathrm{~K}$. Frankle-Kruse also noted their expression was invalid below $900 \mathrm{~K}$; Smith-0'Brasky report a similar threshold of $750 \mathrm{~K}$.

A check on how wear varies with peak bore surface temperatures in guns can be made with bore surface temperature computations by vassallo and coworkers at Calspan Corporation 11 in the M185 cannon. The Calspan workers compute peak bore surface temperatures from measured total heat input. 12 Recent work in a shock-tube gun with different metals showed temperature calculations starting with measured tatal heat input could 


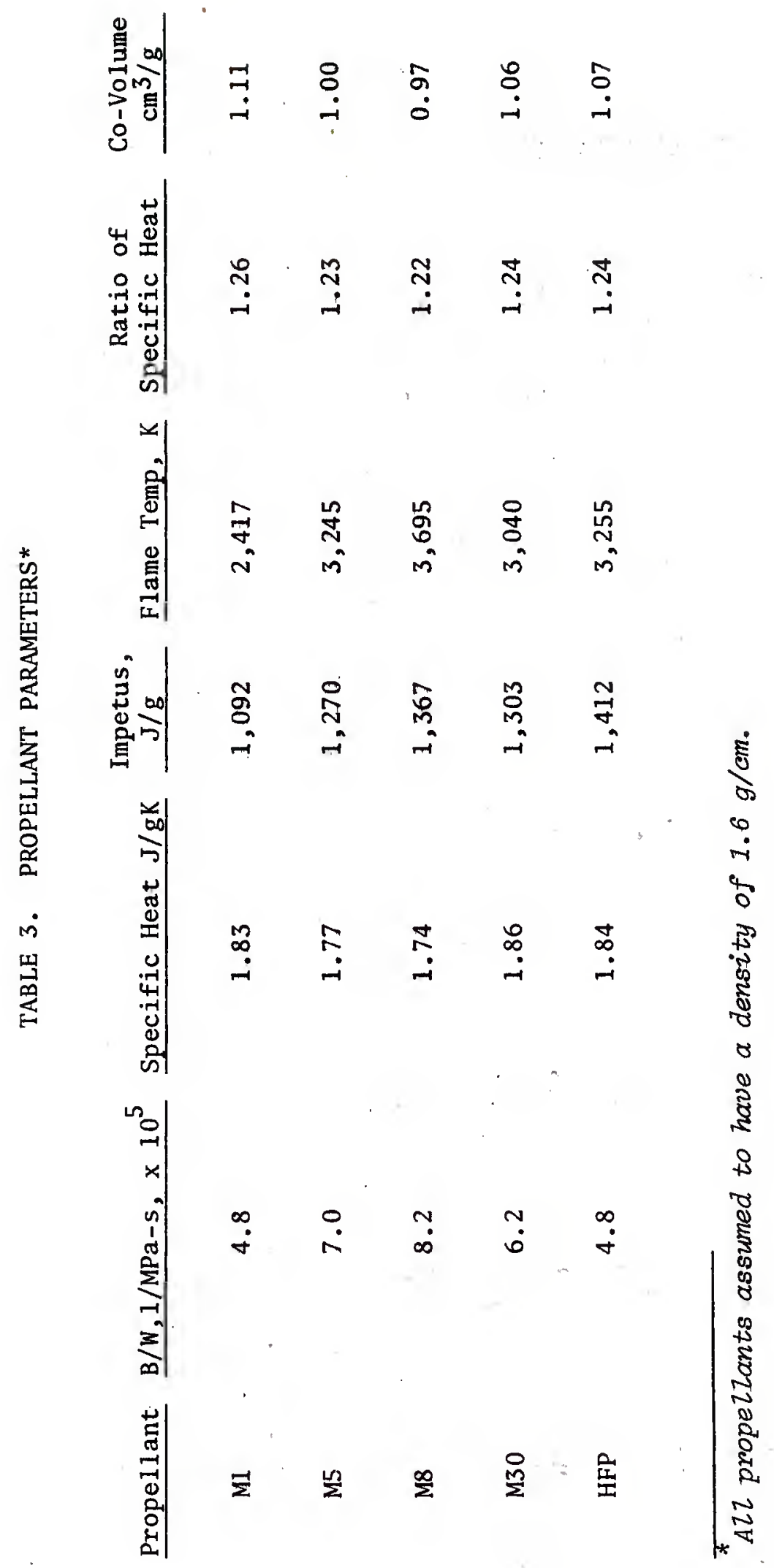


:

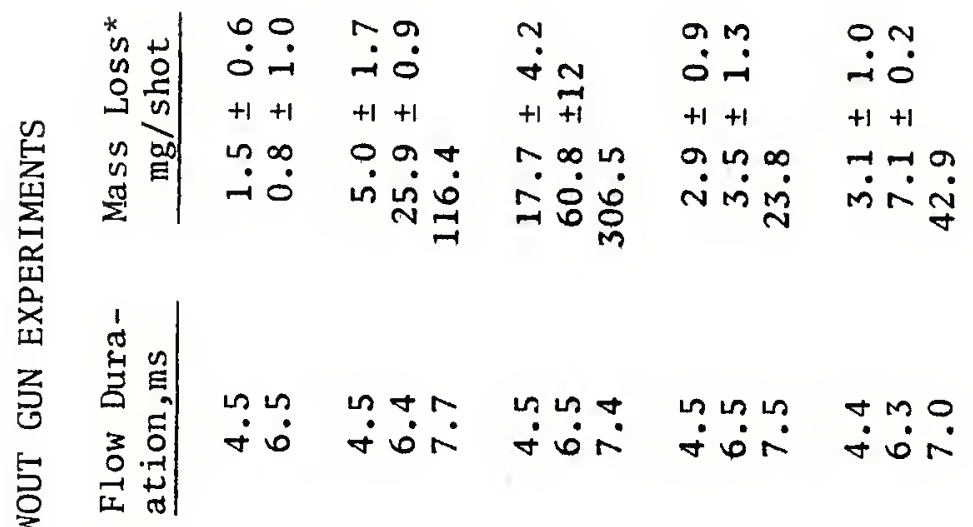

$\infty$

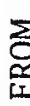

cin

它

焉

누요

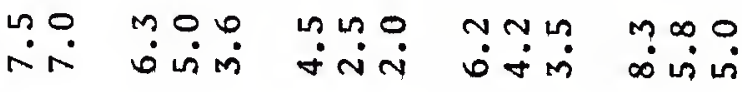

乐承

웅

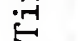

क्ष

会

㲾 0

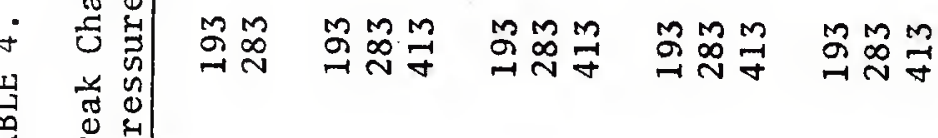

要

$\begin{array}{llll}0 & \\ 0 \\ 0 \\ 0 \\ 0 \\ 0\end{array}$

\begin{tabular}{l}
+ \\
\multirow{2}{*}{} \\
-1 \\
0 \\
0 \\
0 \\
0 \\
0
\end{tabular}

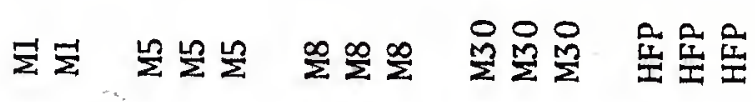




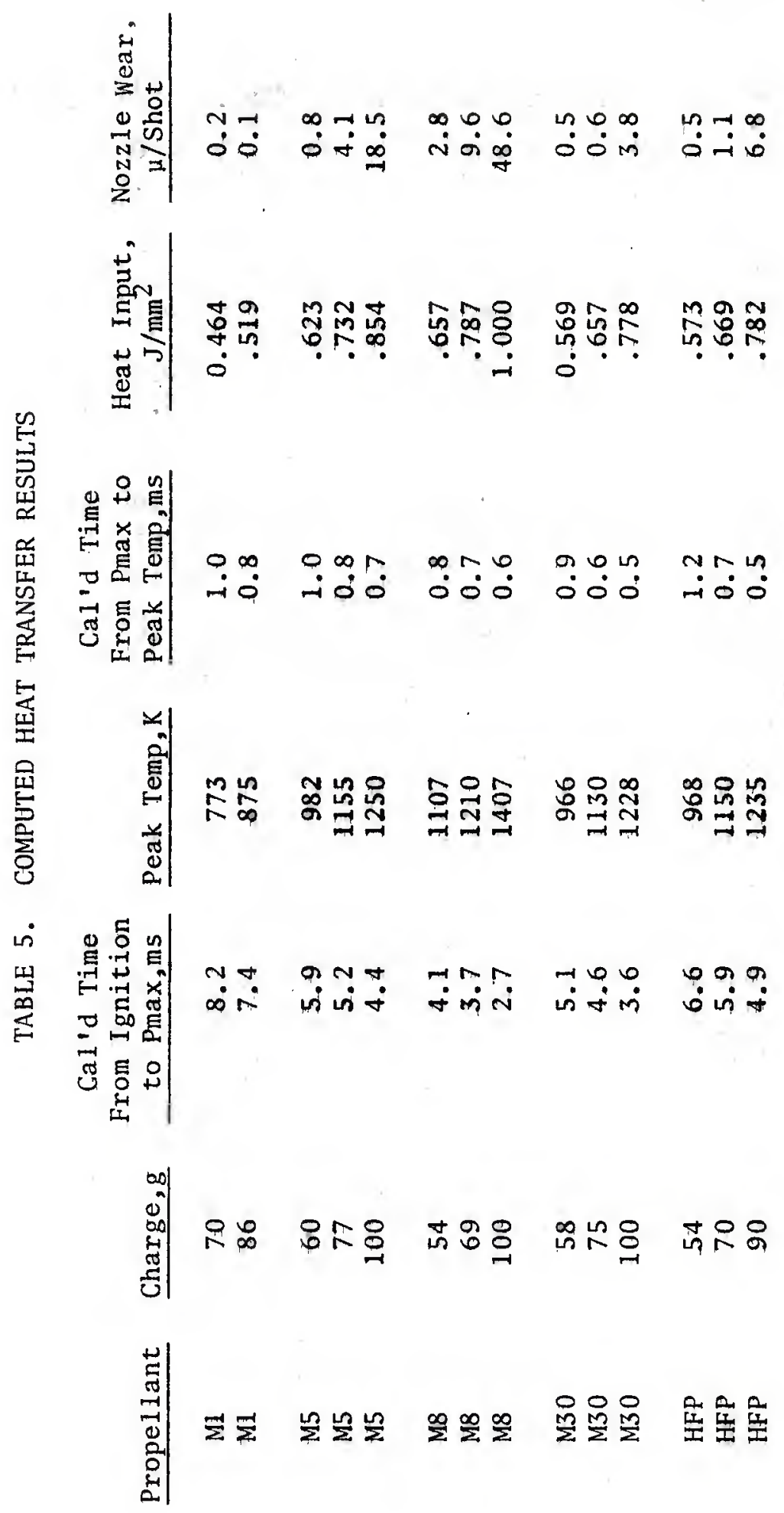


TABLE 6. COMPARISON BETWEEN EXPERIMENTAL WEAR AND WEAR COMPUTED WITH EQUATION (3)

Propellant Peak Temp., $K$ Wear exp't, $\mu /$ Shot Wear Cal'd, $\mu /$ Shot

M1

M1

M30

M30

M30

HFP

HFP

HFP

M5 982

M5 1,155

M5 1,250

M8 1,107

M8 $\quad 1,210$

M8 1,407
0.2

0.1

0.5

0.6

3.8

0.5

1.1

6.8

0.8

4.1

18.5

2.8

9.6

48.6
0,0005

0.2

0.5

2.5

6.2

0.5

3.0

6.6

0.6

3.1

8.3

2.0

5.0

32.1 
predict correctly whether the melting point of the metal was exceeded. Starting conditions in the shock-tube gun were varied to produce temperature bracketing the metals' melting temperatures. 13

Table 7 shows bore surface temperatures computed for three $155 \mathrm{~mm}$ propelling charges which have no wear-reducing additive. Wear data is available for the M119 and the XM201E2 charges, 14,15 Wear sensor data in the M185 cannon showed the XM208 minus its additiye was five times as erosive as the XM201E2. Wear of the XM208 was presumed to be five times greater than the measured wear of the XM201E2 charge. A least-squares fit of the three points in Table 8 to Eq. (3) produced values of $a$ and $b$ of -7.4 and $0.0076 \mathrm{~K}^{-1}$, respectively.

TABLE 7. BORE SURFACE TEMPERATURES AND WEAR FOR 155mm CHARGES WITHOUT ADDITIVE

$\begin{array}{lccc}\text { Charge } & \text { Peak Temp, K } & & \text { Wear, } \mu / \text { shot } \\ \text { M119 } & 961 & 0,9 & \text { Ref. } \\ \text { XM201E2 } & 1,100 & 2.6 & 15 \\ \text { XM208 (no additive) } 1,306 & 12.5 & 16\end{array}$

Figure 1 plots wear vs peak bore temperature for the nozzle and the $155 \mathrm{~mm}$ gun. Figure 1 suggests relative wear among propellants will be overestimated compared with wear in guns by ten percent. Nonetheless, the agreement seems close enough to suggest relative propellant erosivity can be inferred in nozzles.

11F.A. Vassalzo, "An Evaluation of Heat Tnansfer and Erosion in the 155 mm M185 Cannon," CaZspan Technical Report No. VL-5337-D-1, JuZy 1976.

12F.A. VassalZo, "Mathematical Models and Computer Routines Used in Evaluation of Caseless Ammunition Heat Transfer," Calspan Technical Report No. GM-2948-2-1, June 1971.

13 F.A. VassazZo and W.R. Brown, "Shock Tube Gun MeZting Erosion Study," BRL Contractor Report No. 406, August 1979. (AD \#A076219)

${ }^{14}$ J.J. Reed and J.P. Cherry, "Service Tests of 155m Howitzer, SelfPropeiled Equipped with XM185 Tube," Field ArtilZery Board Report. Ft. Sizl, OK, January 1970.

15 J.A. Demaree, "155mm M185 Tube Wear Tests of Charge, PropelZing XM201," Interim Report, JPG-76-601, June 1976. 


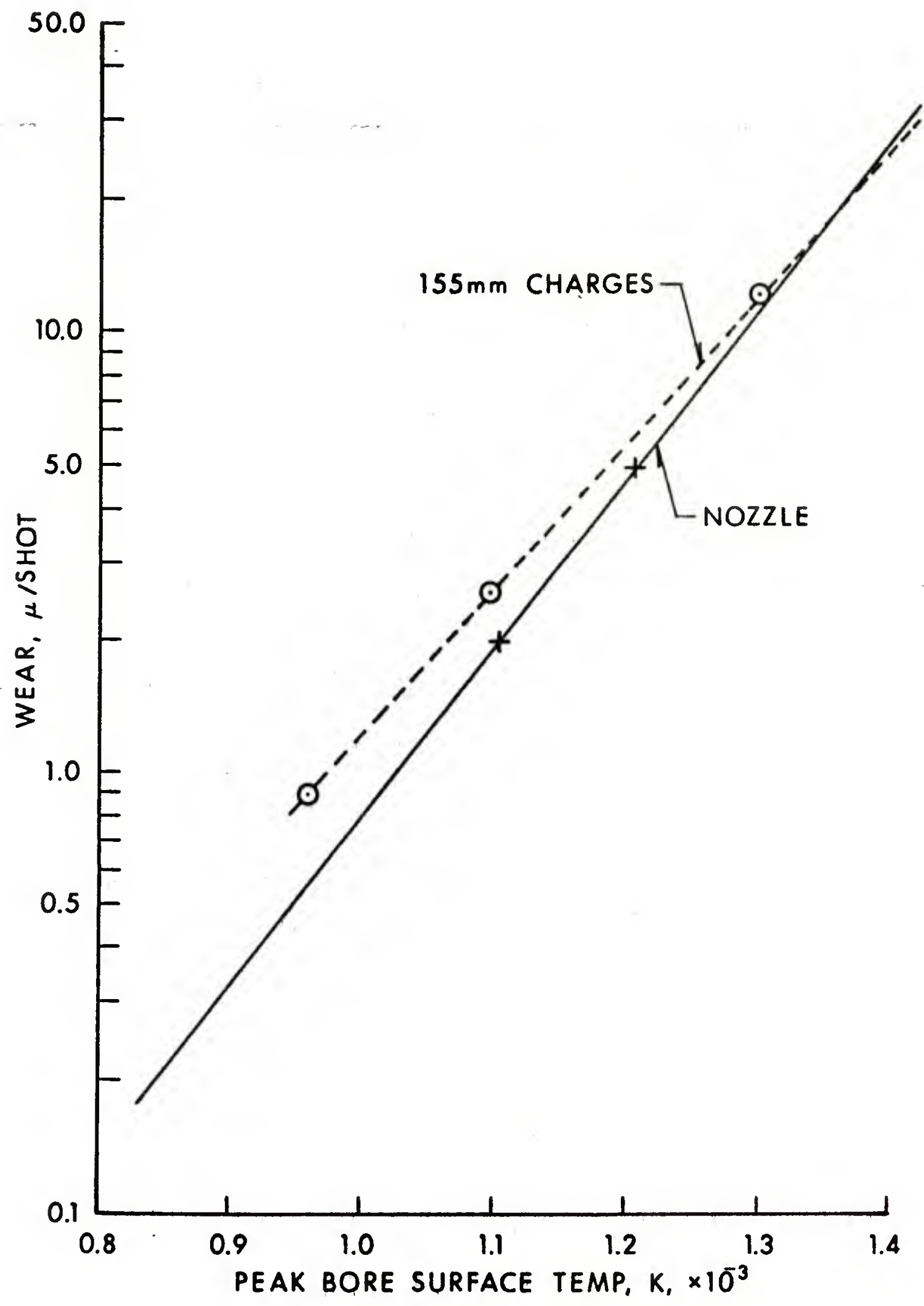

Figure 1. Wear vs Peak Bore Surface Temperature 
Some other observations from the calculations of bore surface temperatures can be made from comparisons of bore surface temperature vs. time for the $37 \mathrm{~mm}$ blowout gun and a $31 / 70$ Naval gun depicted in Figures 2-4. Table 8 summarizes pertinent heat transfer data for the three figures.

TABLE 8. CALCULATED HEAT INPUT AND SURFACE TEMPERATURES FOR $3 " / 70$ AND $37 \mathrm{~mm}$ BLOWOUT GUNS

$\begin{array}{lcccccccc}\text { Gun } & \begin{array}{c}\text { Nozzle } \\ \text { Diameter,mm }\end{array} & \underline{1 / \lambda} & \underline{\text { Propellant }} & \begin{array}{c}\text { Charge } \\ \text { Mass,g }\end{array} & \begin{array}{l}\text { Flame } \\ \text { Temp, K }\end{array} & \begin{array}{c}\text { Surface } \\ \text { Temp, K }\end{array} & \begin{array}{c}\text { Heat In- } \\ \text { put, J/mm }\end{array} \\ 37 \mathrm{~mm} & 17.3 & 253 & \text { HFP } & 89.8 & 3,255 & 1,235 & 0.78 \\ 311 / 70 & - & 280 & \text { Picrite } & 3991 . & 2,065 & 1,224 & 1.13 \\ 37 \mathrm{~mm} & 13.3 & 239 & \text { M1 } & 159 & 2,417 & 1,254 & 1.21\end{array}$

The first point of interest is the short heating time of the blowout gun in Figure $2 \mathrm{vs}$. the $3 " 170$ Naval gun. As a result of the longer heating time, the $311 / 70$ gun reaches the same peak bore surface temperature with a much cooler propellant. The effect of the longer heating time is also reflected in the larger total heat input for the gun. The figures also point out why propellants with flame temperatures near $3800 \mathrm{~K}$ would be needed to get the wear/shot characteristic of tank guns with the $17.3 \mathrm{~mm}$ nozzle. Figure 4 shows that M1 propellant produces an equivalent peak temperature as HFP if charge mass is increased and nozzle diameter is decreased. A new chamber would be required in the $37 \mathrm{~mm}$ gun to be able to load $160 \mathrm{~g}$ of propellant.

\section{CONCLUSIONS}

1. Bore surface temperature vs. time were computed for $17.3 \mathrm{~mm}$ diameter nozzles in the BRL $37 \mathrm{~mm}$ blowout gun in order to test dependence of wear vs. peak bore surface temperature.

2. The natural logarithm of wear from the nozzle was shown to be linearly dependent on peak bore surface temperature which agrees with empirical wear models and with calculations of peak bore surface temperatures by Calspan Corp. for the $155 \mathrm{~mm}$ Ml85 cannon. It was shown the slope is $10 \%$ steeper in the nozzle suggesting relative propellant erosivity with the $17.3 \mathrm{~mm}$ diameter nozzle may be exaggerated slightly compared to large caliber guns. 


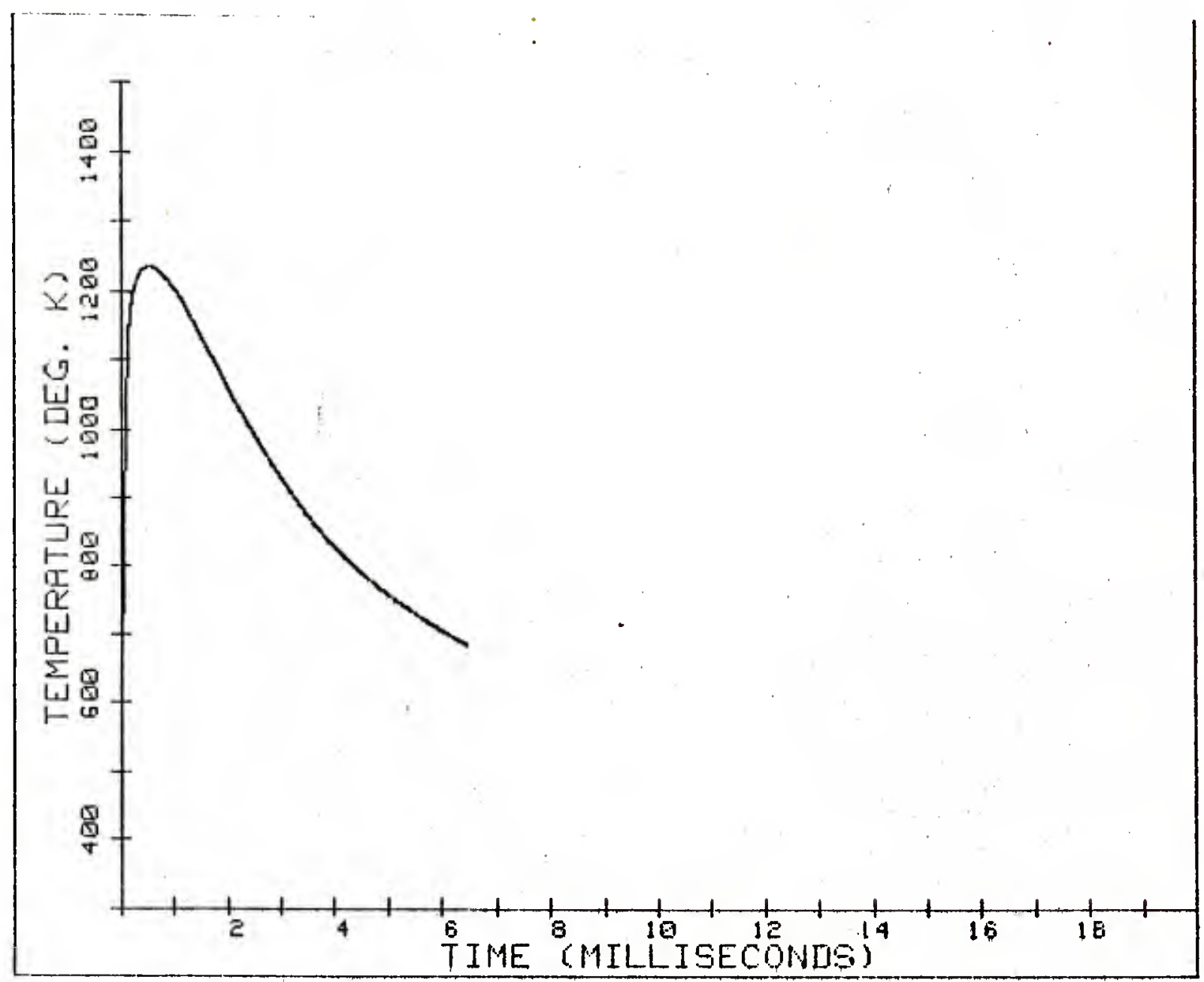

Figure 2. Temperature vs. Time in $37 \mathrm{~mm}$ Blowout Gun (17.3mm Diameter NozzTe-HFP Propellant). 


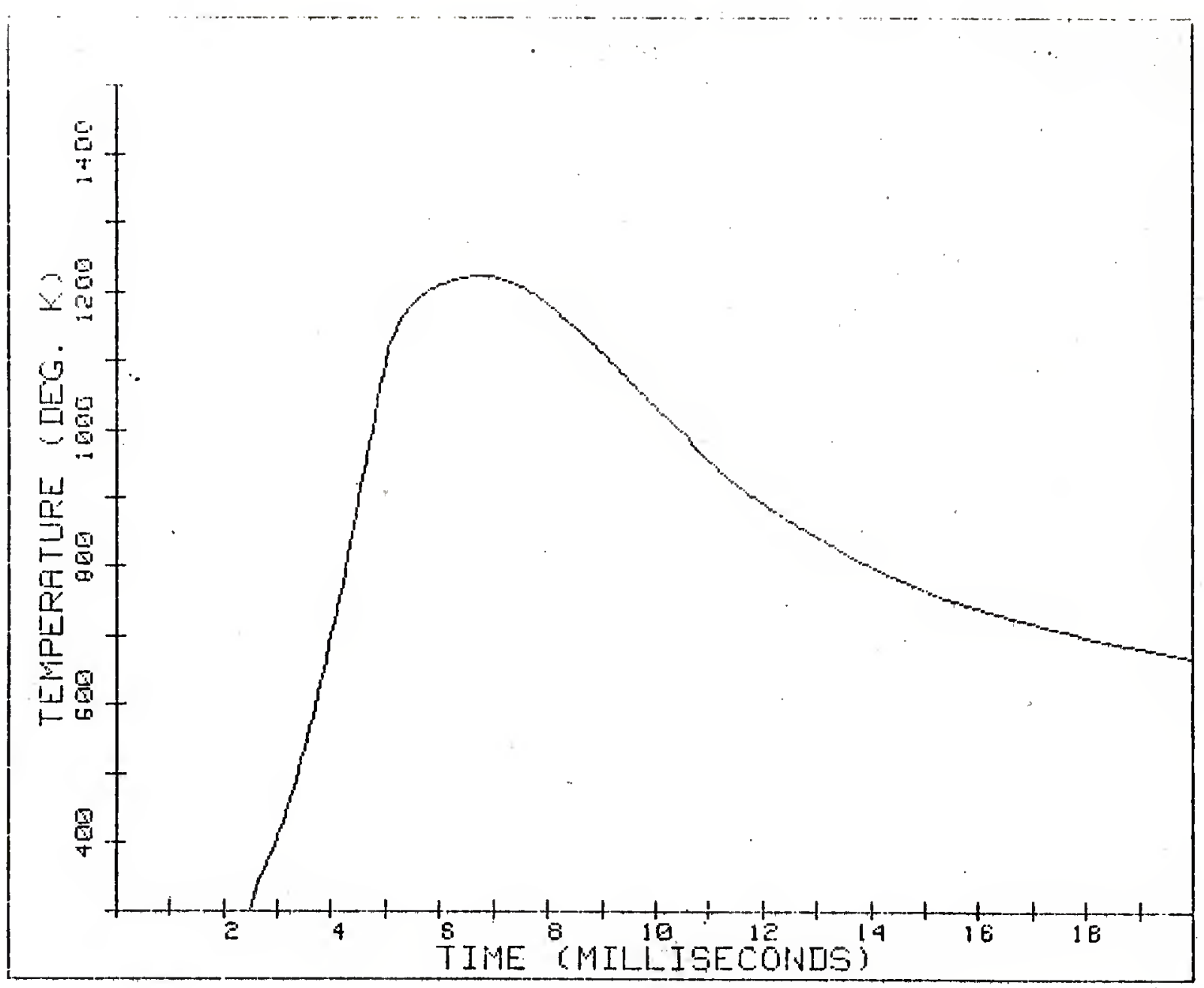

Figure 3. Temperature vs. Time in $3 " / 70$ Gun With Picrite Propellant. 


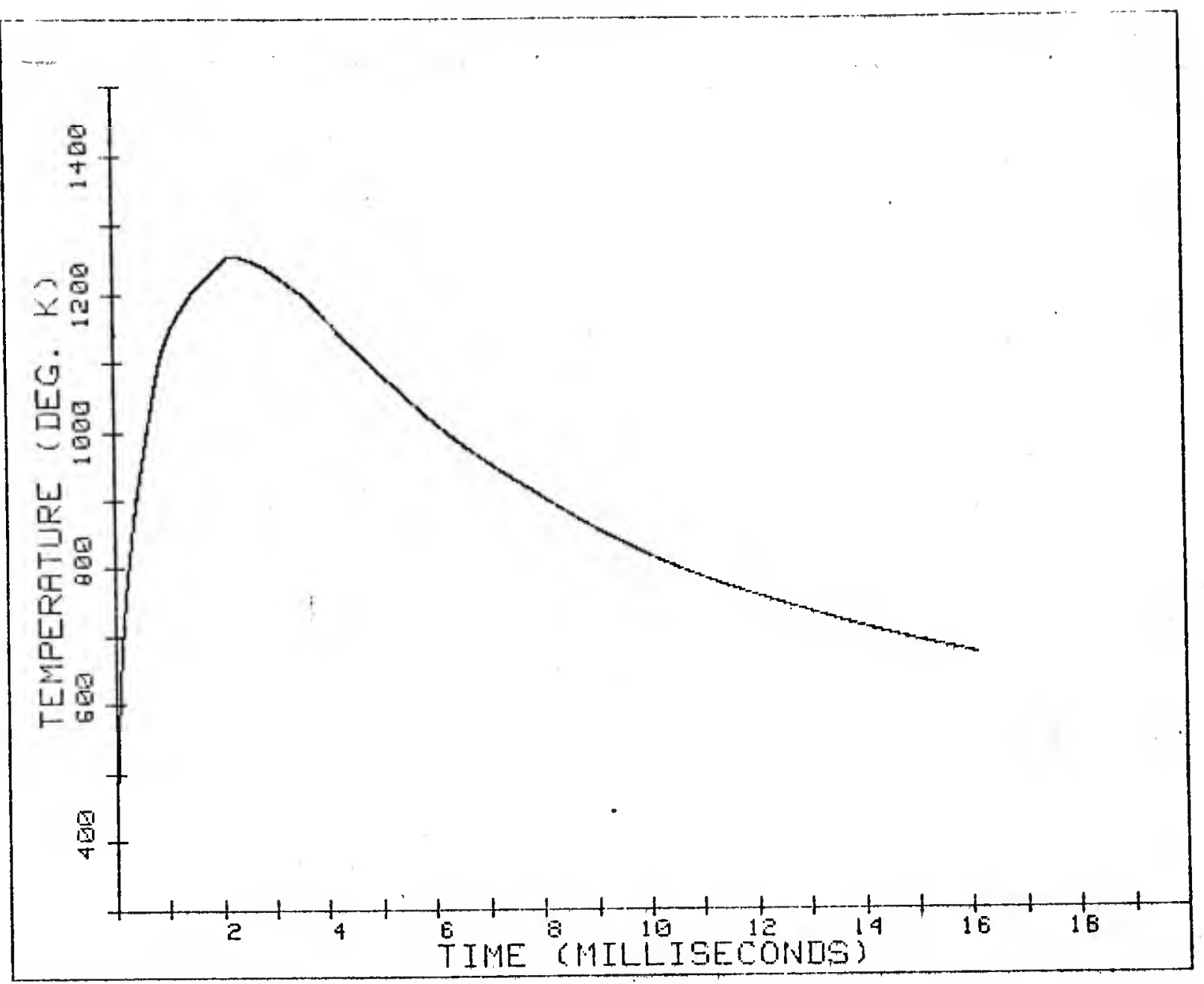

Figure 4. Temperature vs. Time in $37 \mathrm{~mm}$ Blowout Gun $(13.3 \mathrm{~mm}$ Diameter NozzTe-Mi Propellant). 


\section{REPERENCES}

1. "Hypervelocity Guns and the Control of Gun Erosion," Summary Technical Report of Division 1, NDRC, Volume 1, Washington, DC, 1946.

2. J.A. Lannon and J.R. Ward, "Workshop Report on Wear-Reducing Additives and Their Performance in Guns," to appear in the Proceedings of the $17 \mathrm{th}$ JANNAF Combustion Meeting.

3. A.J. Bracuti, L. Bottei, J.A. Lannon, and L.H. Caveny, "Evaluation of Propellant Erosivity With Vented Chamber Apparatus," 1980 JANNAF Propulsion Meeting, CPIA Publication 315, March 1980.

4. J.R. Ward, R.W. Geene, A. Niiler, A. Rye, and B.B. Grollman, "Blowout Gun Erosivity Experiments with Double-Base, Triple-Base, and Nitramine Propeliants," 1980 JANNAF Combustion Meeting, CPIA Publication 315, March 1980.

5. J.M. Frankle and L.R. Kruse, "A Method for Estimating the Service Life of a Gun or Howitzer," BRL Memorandum Report 1852, June 1967. (AD \#818348)

6. C.S. Smith and J.S. 0'Brasky, "A Procedures for Gun Barrel Life Estimation," Proceedings of the Tri-Service Gun Tube Wear and Erosion Symposium, ADPA. Dover, NJ, March 1977.

7. J. Corner, Theory of the Interior Ballistics of Guns, John Wiley \& Sons, Inc., $\overline{N Y, 1950 .}$

8. L.W. Nordheim, H, Soodak, and G. Nordheim, "Thermal Effects of Propellant Gases in Erosion Vents and Guns," NDRC Armor and Ordnance Report No. A-262, March 1944.

9. R.W. Geene, J.R. Ward, T.L. Brosseau, A. Niiler, R. Birkmire, J.J. Rocchio, "Erosivity of a Nitramine Propellant," BRL Technical Report No. 02094, August 1978. (AD \#A060590)

10. S.E. Caldwel1 and A. Niiler, "The Measurement of Wear from Steel Using the Radioactive ${ }^{56} \mathrm{Co}$, "BRL Report No. 1923, September 1976. (AD \#A030262)

11. F.A. Vassa110, "An Evaluation of Heat Transfer and Erosion in the 155mm M185 Cannon," Calspan Technical Report No. VL-5537-D-1, July 1976.

12. F.A. Vassal1o, "Mathematical Models and Computer Routines Used in Evaluation of Caseless Ammunition Heat Transfer," Calspan Technical Report No. GM-2928-Z-1, June 1971.

13. F.A. Vassallo and W.R. Brown, "Shock Tube Gun Melting Erosion Study," BRL Contract Report No. 406, August 1979. (AD \#A076219) 


\section{REFERENCES (Cont'd)}

13. F.A. Vassallo and W.R. Brown, "Shock Tube Gun Melting Erosion Study," BRL Contract Report No. 406, August 1979.

14. J.J. Reed and J.P. Cherry, "Service Tests of $155 \mathrm{~mm}$ Howitzer, SelfPropelled Equipped with XM185 Tube," Field Artillery Board Report, Ft. Sil1, OK, January 1970.

15. J.A. Demaree, "155m M185 Tube Wear Test of Charge, Propelling XM201," Interim Report, JPG-76-601, June 1976. 
APPENDIX

COMPUTER CODES 


\section{COMPUTER CODES}

The first program, "IB3/70", computes interior ballistics data for guns.

The second program, "NOZZLE", computes interior ballistics data for a blowout gun with an erosion nozzle.

The third program, "newnsn" computes heat transfer and conduction data. The program "newnsn" uses information stored on files "DATA" and "DATA1" by "IB3/70" or "NOZZLE". 
Input data begins in line 2860. Data to be stored in each line is as follows:

\begin{tabular}{|c|c|}
\hline Line & Data \\
\hline 2860 & Projectile weight (1bs) \\
\hline 2870 & Projectile travel (inches), chamber volume (cu.in.) \\
\hline 2880 & Pidduck-Kent constant, integration step size (sec) \\
\hline 2890 & $\begin{array}{l}\text { Estimated projectile velocity }(\mathrm{ft} / \mathrm{sec}) \text {, bore diameter(in), } \\
\text { bore area (sq.in.) }\end{array}$ \\
\hline 2900 & Shot start pressure (psi) \\
\hline 2910 & Igniter weight (pounds) \\
\hline 2920 & $\begin{array}{l}\left.\text { Igniter impetus (in } 1 b_{f} / 1 b_{m}\right) \text {, ratio of specific heats, } \\
\text { flame temperature }\left({ }^{\circ} \mathrm{K}\right) \text {, covolume (cu.in./lb) }\end{array}$ \\
\hline 2930 & Propellant weight (lbs) \\
\hline 2940 & $\begin{array}{l}\left.\text { Propellant force (in } 1 b_{f} / 1 b_{m}\right) \text {, ratio of specific heats, } \\
\text { flame temperature }\left({ }^{\circ} \mathrm{K}\right) \text {, covolume (cu.in./1b), density (lb/cu.in.) }\end{array}$ \\
\hline 2950 & $\begin{array}{l}\text { Propellant grain diameter (in), length (in), perforation dia- } \\
\text { meter (in), and number of perfs }\end{array}$ \\
\hline 2960 & Propellant identification (an alphanumeric string) \\
\hline 2970 & $\begin{array}{l}\mathrm{P} 1, \mathrm{~B} \text { (where the burning rate (in/sec) is } \mathrm{B}^{*}(\mathrm{space} \text { mean } \\
\text { pressure in psi }+\mathrm{P} 1)) \text {, number of integration steps per } \\
\text { printout, expected peak chamber pressure (psi), expected } \\
\left.\text { peak acceleration ( } \mathrm{g}^{\prime} \mathrm{s}\right) \text {. }\end{array}$ \\
\hline 2980 & $\begin{array}{l}\text { Number of "resistive pressures" listed, followed by the } \\
\text { appropriate number of pairs of travel distance(in) and } \\
\text { resistive pressure (1b/sq.in.) }\end{array}$ \\
\hline $2990-3020$ & $\begin{array}{l}\text { These lines are used by the program to aid in calculating } \\
\text { the fraction of the } 7 \text { perf grain burnt after splintering. }\end{array}$ \\
\hline 3025 & $\begin{array}{l}\text { Use this line to provide data if called for by the input } \\
\text { statements }\end{array}$ \\
\hline
\end{tabular}

Data requested by input statements:

"Number of parameters to be varied": Enter a number ( 0 to 5 ).

"Number of proj wt, cham vol, pmax, travel distance, charge wt": The number of non-zero enteries should be as indicated in the immediately previous input. The values for the parameters indicated should have been listed in line 3025 of the program.

"Option No 2" below:

Enter a number ( 0 to 7$)$. The program will then perform as indicated 
NUMBER ENTERED

0

1

2

3

4

5

6

7
ACTION

Compute IB trajector for input data (i.e., data in lines 2860-2980)

Change $B$ to match indicated peak pressure

Change charge weight to match indicated pressure

Change $B$ to match indicated acceleration

Change charge weight to match indicated acceleration

Change charge weight to match indicated velocity

Print out a blurb of the above

Same as 0 , but program writes data on files DATA DATAl for future use.

Note that if the first input requested was not zero multiple runs will be performed. This is not useful if "Option number 2 " is 7 . 


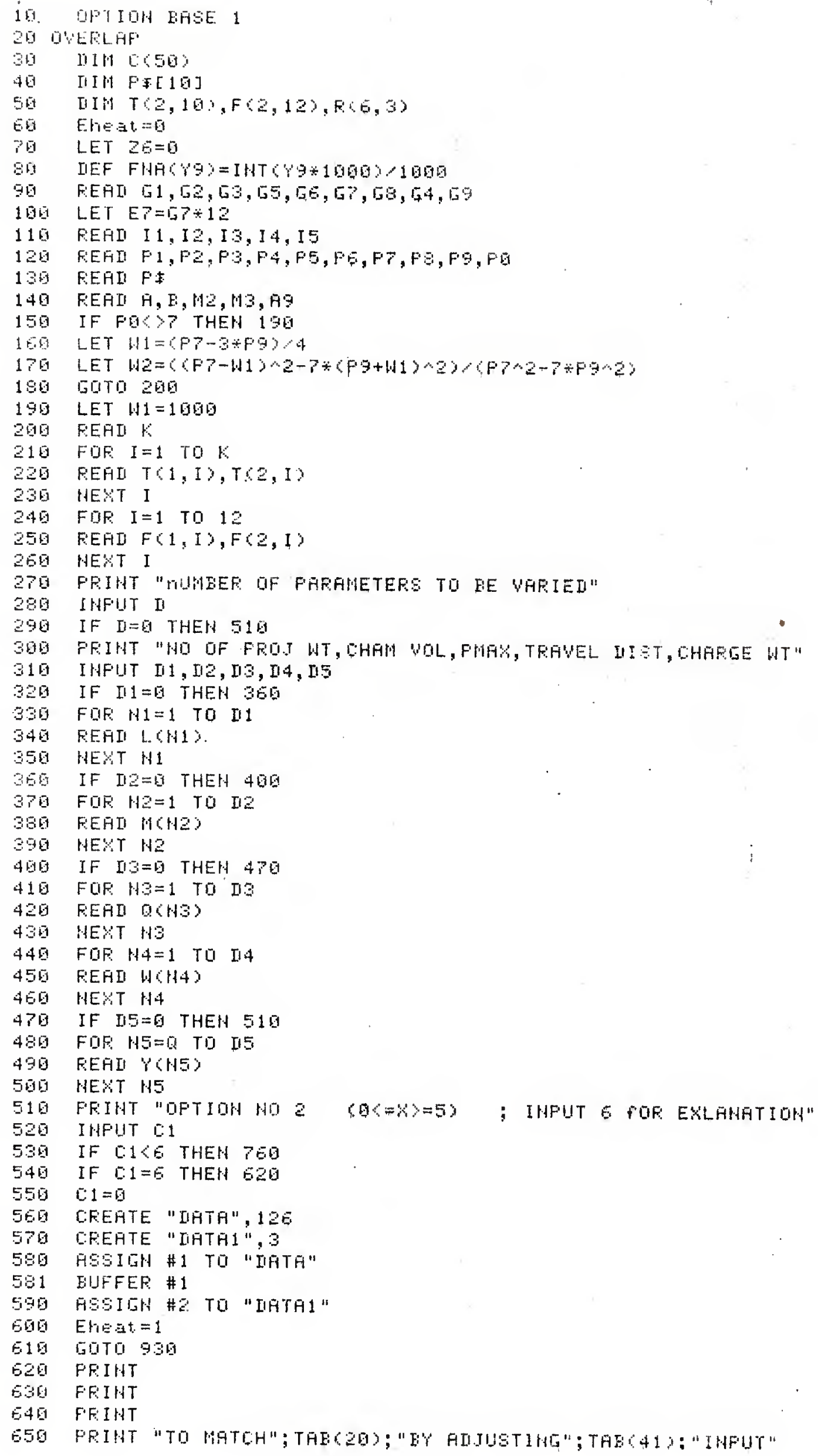




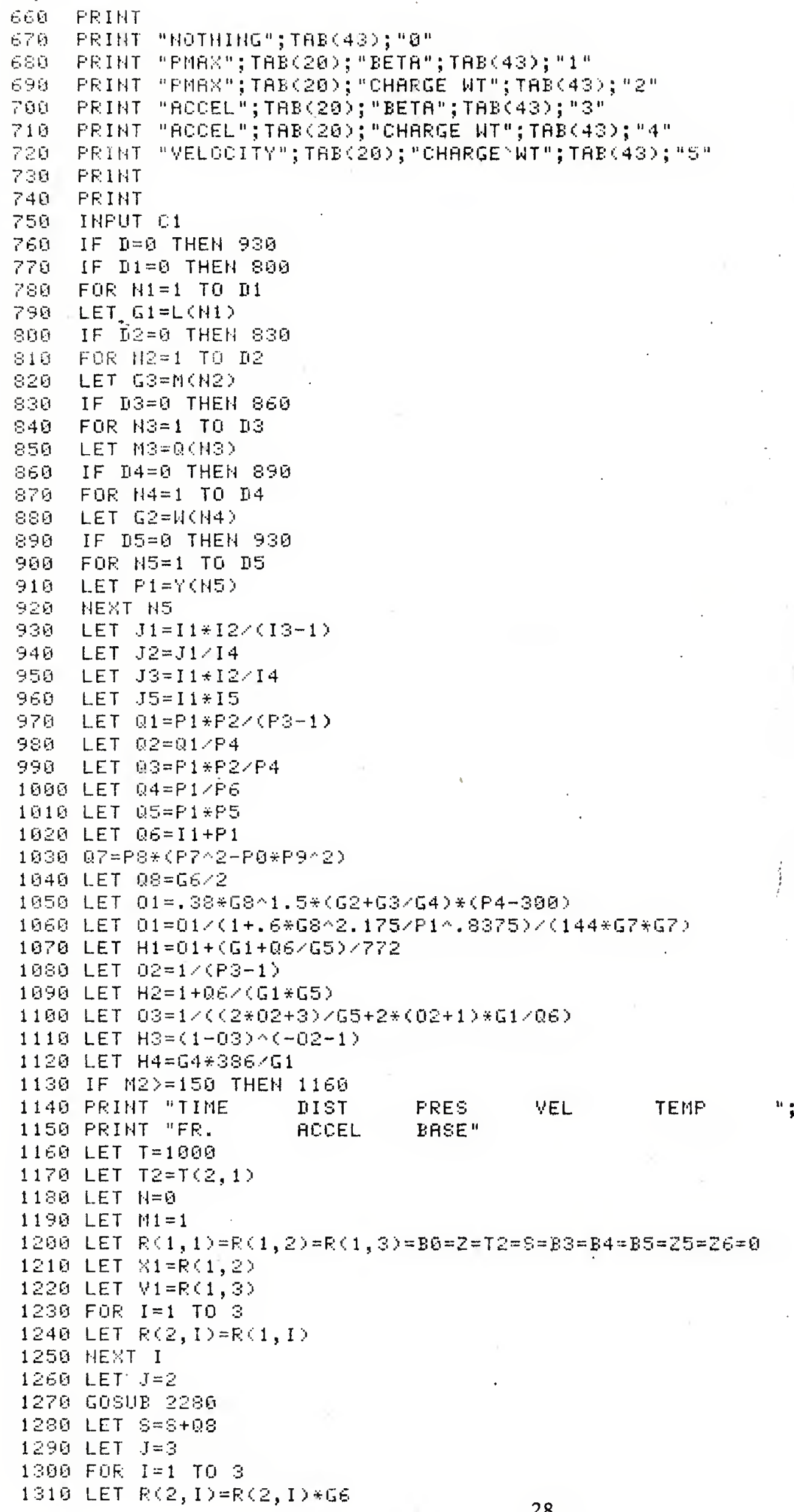




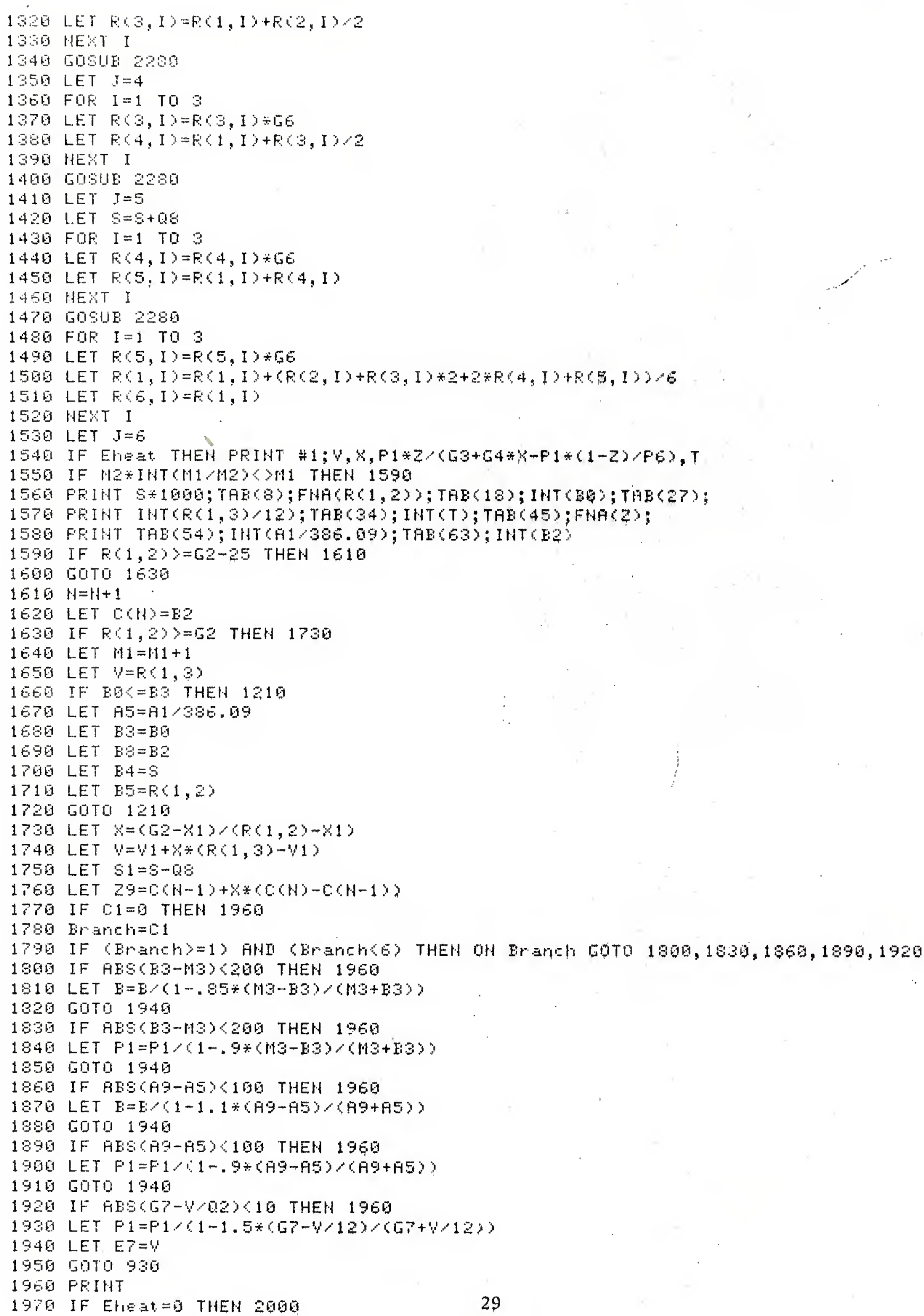




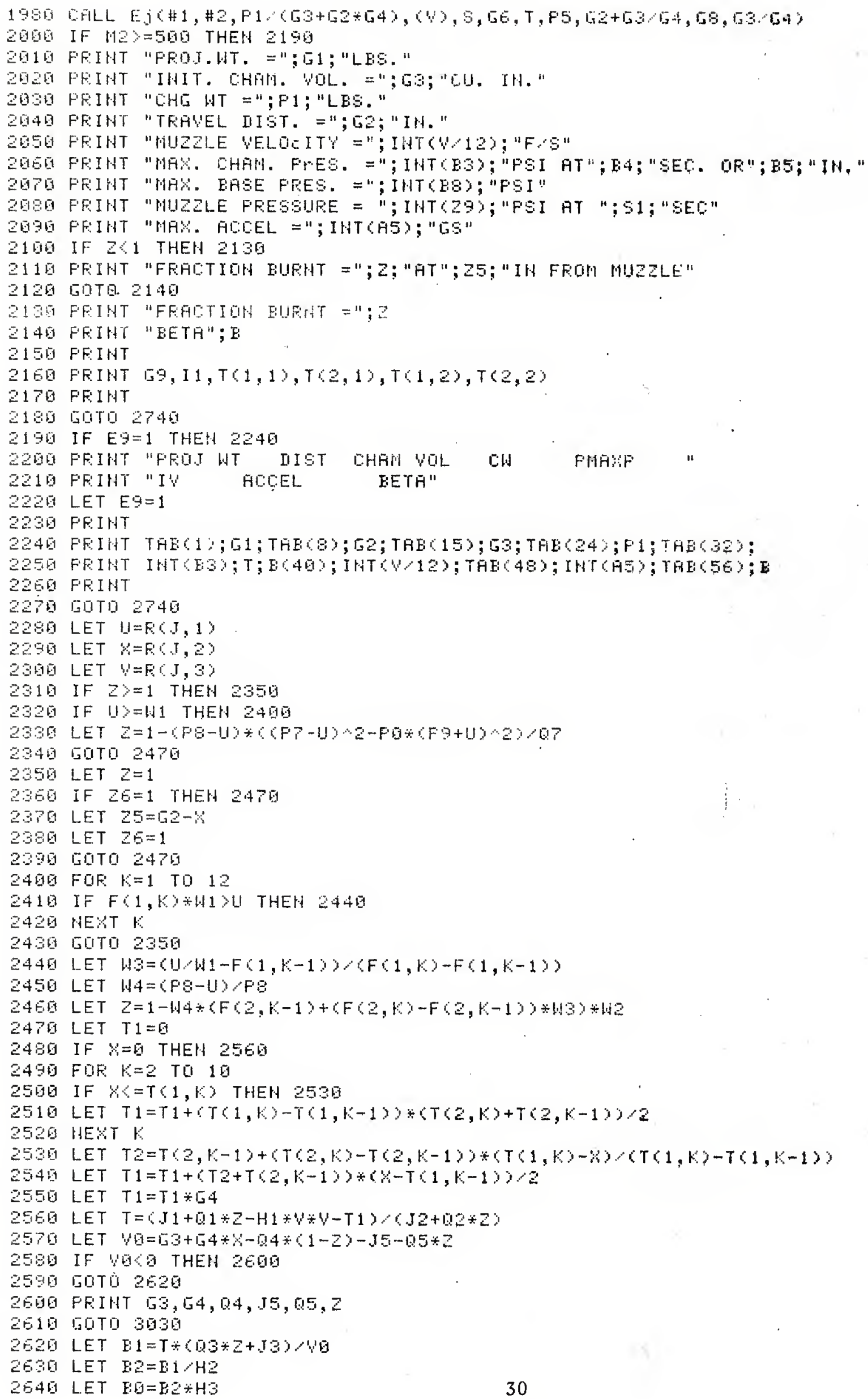




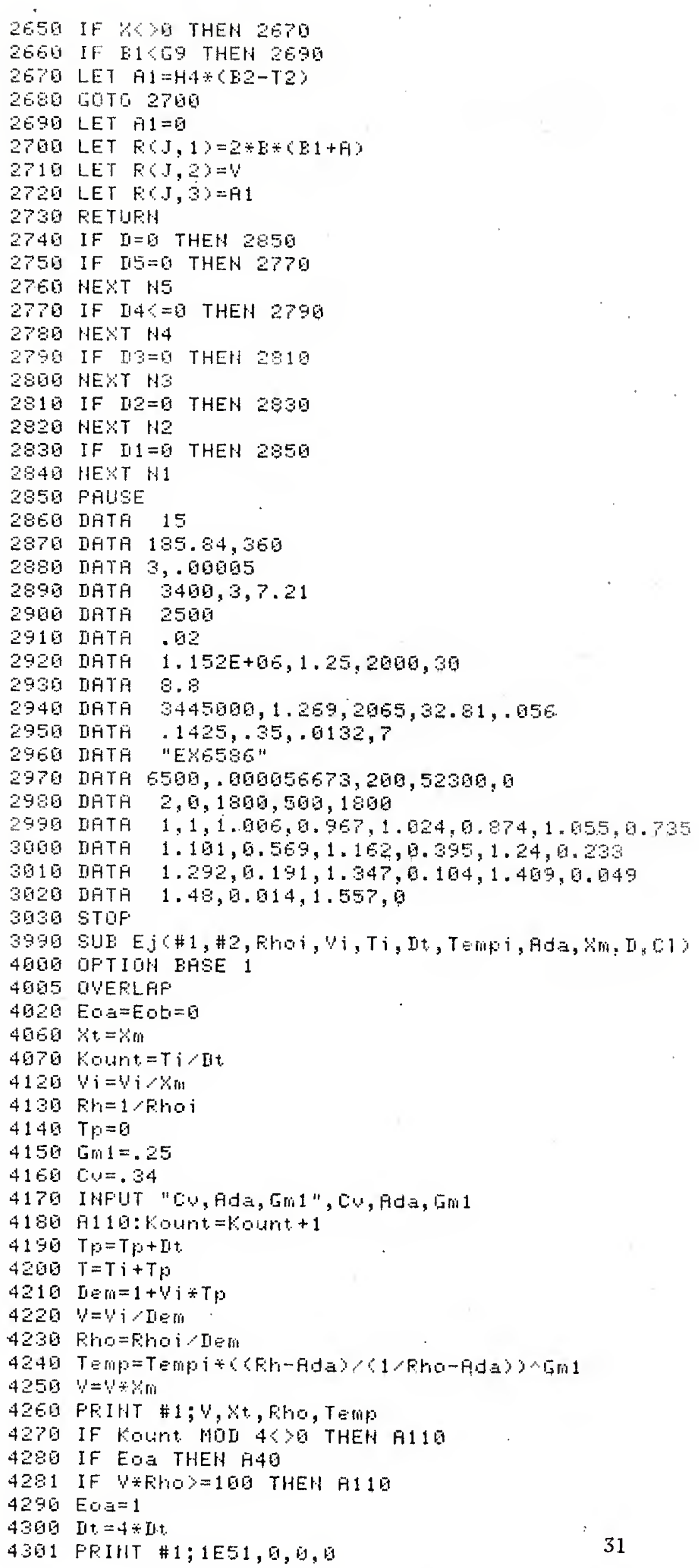


4365600 F110

4310 A4⿴囗 IF FHO =.00550 THEH Ä110

4315 FFIHT \#1;1E51, 6, 0, 0

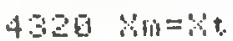

4398 IIt $=I t / 4$

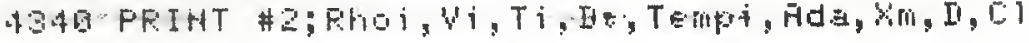

$43 E D$ SUEEHD

4370 END 
Input data is lines 110 and 120 corresponds to the READ statements of lines 20 and 30 . Input dat is as follows:

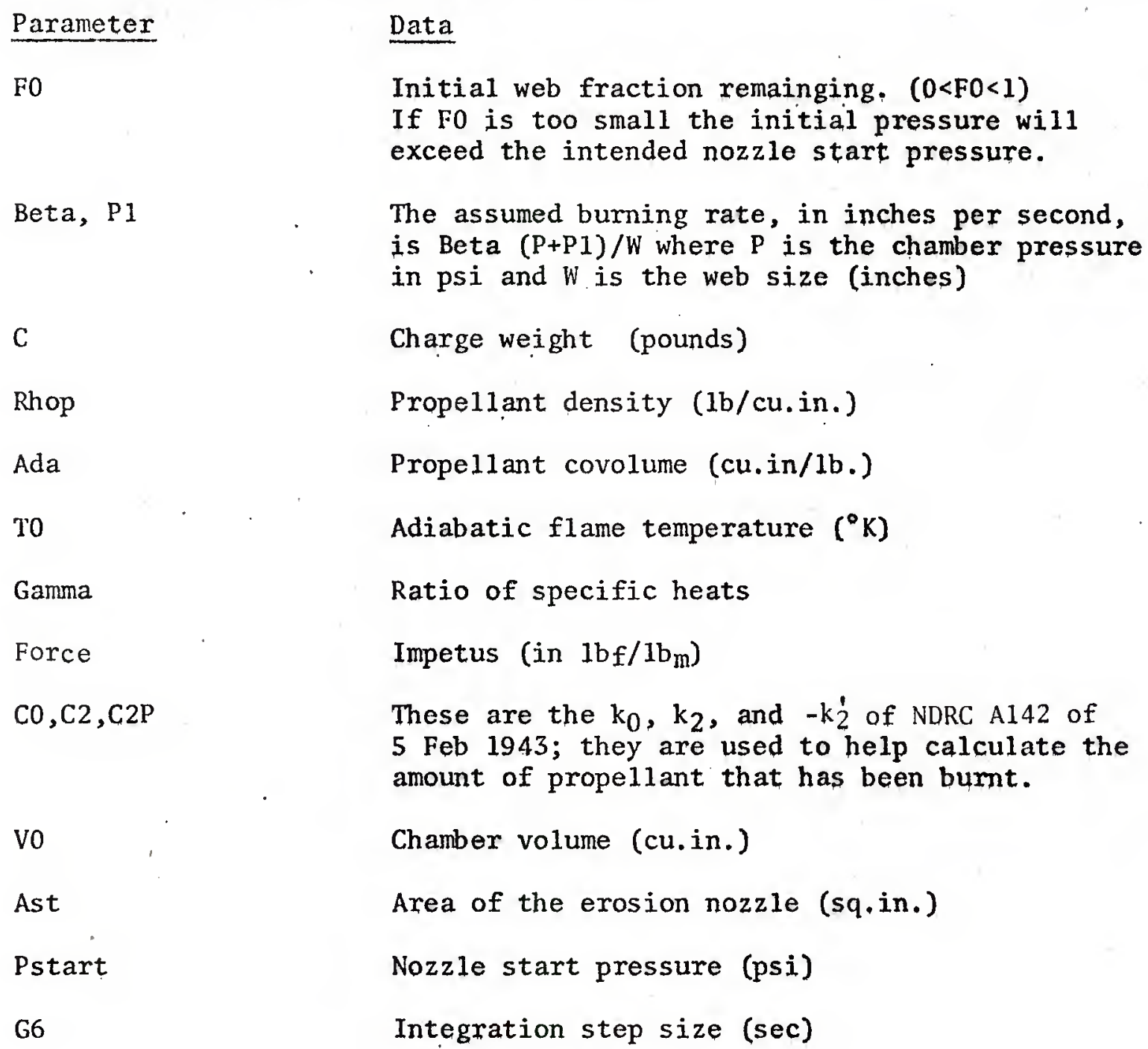


DUERLFF

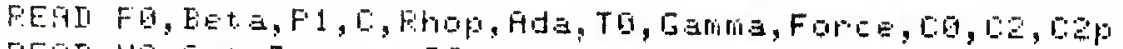

FEAI VB, $\bar{A} \equiv t, F=t$ art, $D E$

$\Xi \mathrm{i}=5=\mathrm{G}$

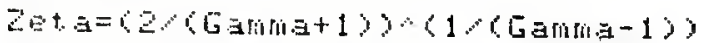

$E_{F}=(1-2 * 2 e t a) / G$ antia

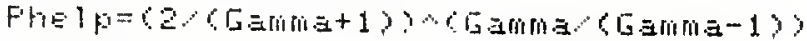

$08=1,6,2$

Erre $\bar{x}:=0$

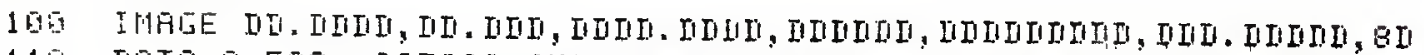

110 IATA $0.569, .065200,6506, .009, .057,32.81,2065,1.269,3445050, .0502, .1329, .367$

1

1 IVI IATA $19.2,0690,41005, .000050$

$130 \quad F(1 ;-1)=F G$

140 F $1,2 y=0$

150 kount $=\overline{0}$

160 CREATE "IATA", 126

170 CREATE "DATAI", 3

180 ASSIEH \# I TO "IATA"

190 ASSIGH \#2 TO "IIATAI"

206 EUFFER \#1

216 FDF $I=1$ TO 2

221 LET $F(2, I)=R(1, I)$

230 HEXT I

246 LET $J=2$

250 GUSUE EEA

206 LET $8=8+08$

270 LET $\mathrm{I}=3$

280 FOF $I=1$ TO 2

290 LET $\mathrm{R}(2, I)=R(2, I) \div[E$

301日 LET F(3, I) $=8(1, I)+F(2, I) / 2$

310 HEXT I

320 GREUE ER

330 LET $J=4$

340 FOF: $I=1$ TO 2

350 LET $F(3, I)=F(S, I) * 5 E$

$36 \overline{1}$

370

360

390

406

410

420

430

446

450

460

476

LET $R(4,1)=F(1,1)+F(3, I), 2$

HEYT I

GOSUE 669

LET $J=5$

LET $s=8+\theta$

FOF $I=1$ TO ?

LET $F(4, I)=F(4, I) * G E$

LET $R(5, I)=R(1, I)+F(4, I)$

NEXT I

LOSUE 660

FOF $I=1$ TD 2

LET $F(5,1)=F(5,1) * 156$

LET $F(1, I)=R(1, I)+(R(2, I)+R(3, I) * 2+2 * R(4, I)+R(5, I))<$

LET $R(E, I)=R(1, I)$

HEXT I

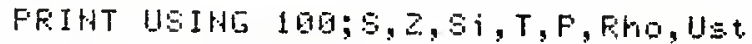

IF $U \equiv t=0$ THEN 210

Kount $=$ Kount +1

FPIHT \#1;UEt, 1 , Fhast, T $\leq t$

IF Kount MOD $43>0$ THEH 210

IF HOT Ereak OR (Fho〉.0195) THEN 210

570 IF 51 THEH $\$ 1 a$

$580 \quad 51=1$

590 FEIHT \#1;1E51,0, 日, 0

$6.0960=4 \div G E$

$605 \quad 08=4 \div 98$

$610 \quad 6070210$

615 g1a: IF RHos. 001 THEH $21 \mathrm{H}$

EZE FEIHT \#1;1E51, 9, 0,0

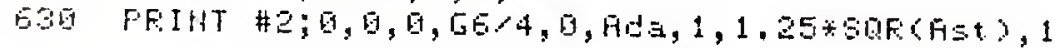


640 LORI "newnsn"

E50 STOF

EEG $F=R(J, 1)$

S7G $S i=R(1,2)$

ESG $Z=(1-F) *(D Q+C 2) * F)$

096 IF $Z>1$ THEH $Z=1$

7日O IF $F>0$ THEH $Z=(1-F) *(C D+C Z * F)$

710 IF $F<-.5$ THEH $Z=1$

720 Zhelp=Vo-C*(1-2) Rhop

730 VPres=2help-(C*2-3i)*Ada

$740 \quad \psi t h=2 h=1 p-c * 2 *$ Hda

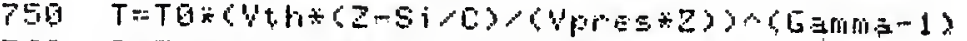

760

779

780

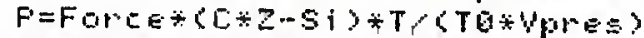

790

Ereak =Ereak OR (P>F $=t$ art?

Rho $=0 \div 2-S i) / 2 h=1 p$

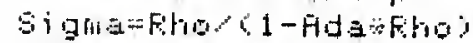

S00 $F(j, 1)=-B E t a *(P+F 1)$

819. IF HOT EREak THEH RETUFH

S20 HElper $=E$ EFHda*Sigma

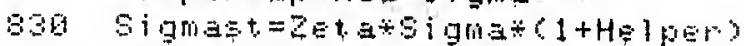

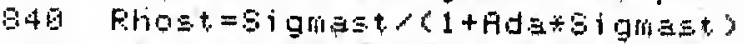

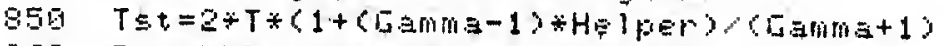

Be日 Fst=Fhelp*P*C1+Ganma*Helper)

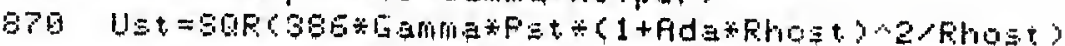

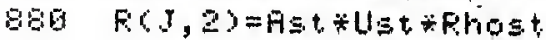

895 RETURH 


\section{"newnsn"}

The data listed in this program should not normally be changed. Input parameters are requested as indicated below. Default values are as indicated.

Message

0 FOR GRAPHS, 1 FOR NO GRAPHS TIMM, TEMPM

ENTER LABEL

GUN TEMPERATURE?

ALCP
XINT, TINT

NRDS, NLA, IPROPT, LHELP

INSIDE DIAMETER, OUTSIDE DIAMETER
Keyboard Entry.

0 or 1

Maximum time (sec) and temperature

$\left({ }^{\circ} \mathrm{K}\right)$ to be shown on graph

An alphanumeric label for the graph

Temperature of gun steel (default is $300^{\circ} \mathrm{K}$ )

$\lambda^{\star} \mathrm{C}_{\mathrm{p}}$ (default is $0.4 /\left(14.8+4{ }^{*} \log _{10} \mathrm{D}\right)^{2}$, where $D$ is the gun caliber in centimeters) Distance from idealized breech (inches) for these calculations, time to stop calculations or go to next round (sec) (default = projectile base or nozzle throat, $D / 100$ )

Number of rounds in this burst, number of mathematical layers, print option (0 for ful1 print, 1 for $1 / 4$ as much, 2 for very little printing), mathematical layer to use for bore surface between rounds (default: $1,7,0,4$ ) Inside and outside diameter of the gun (inches) 


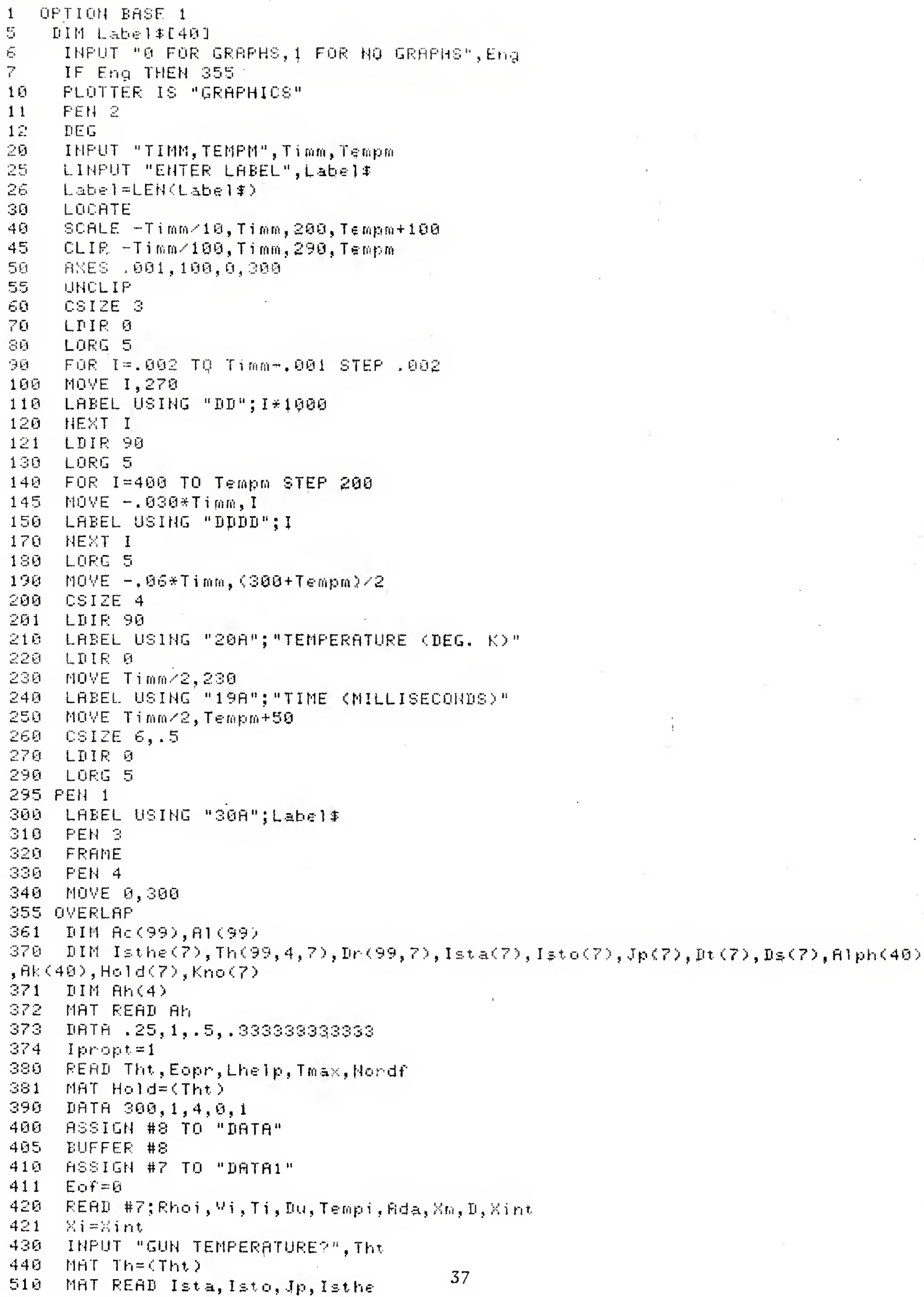




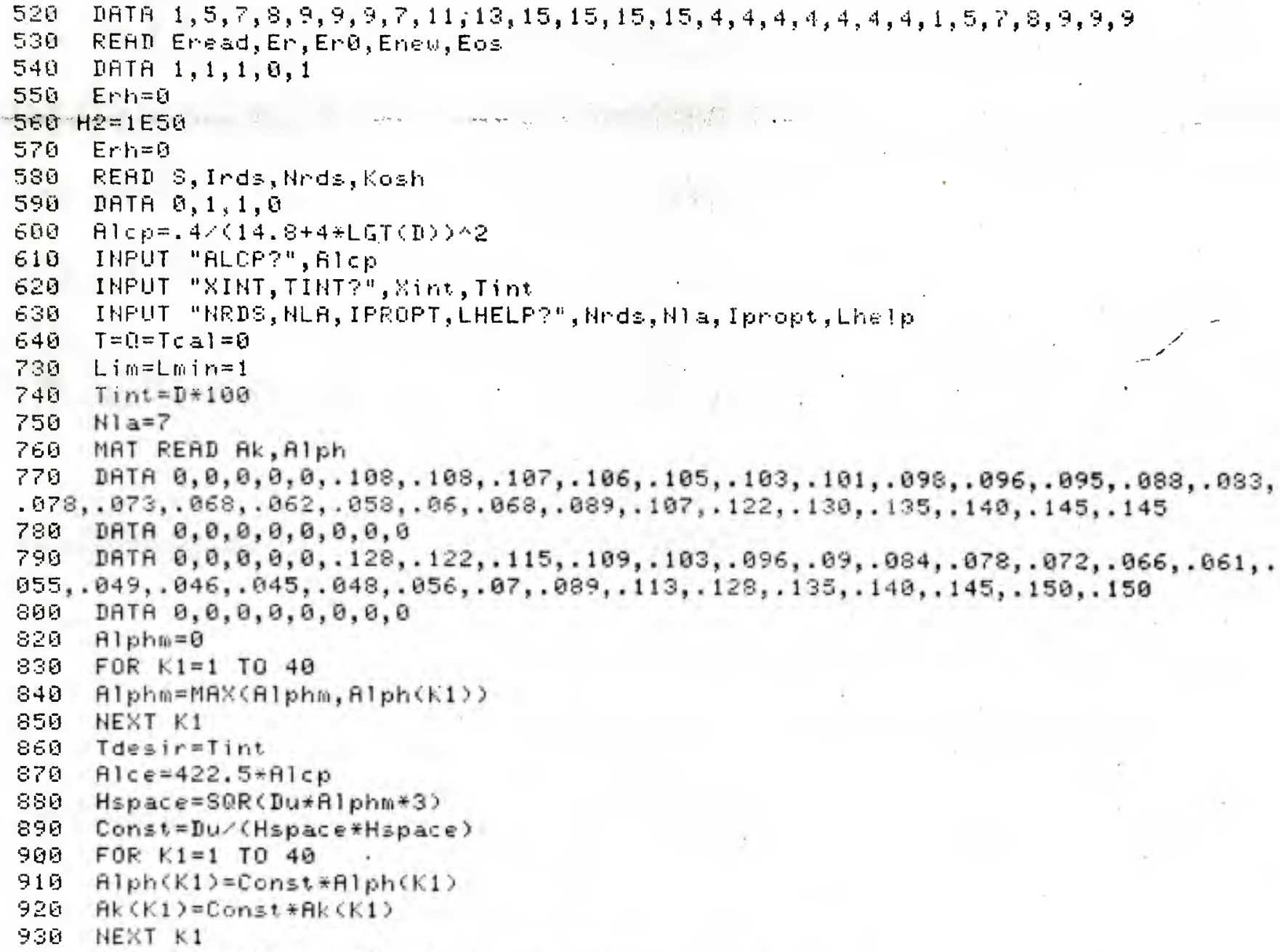




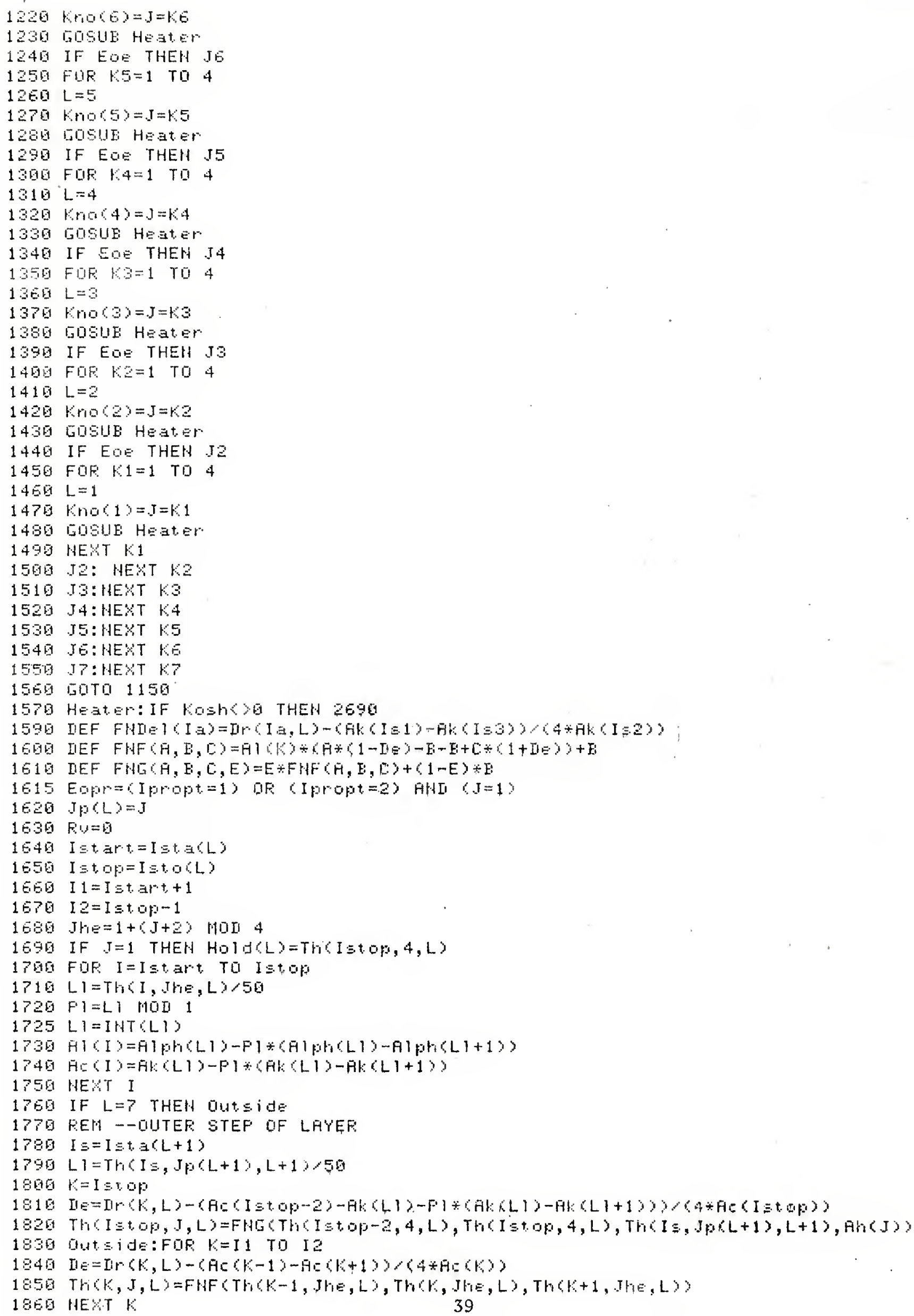




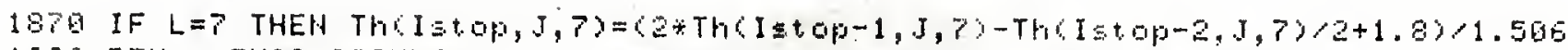

1830 REM - THIS ASSUMES $K=.11, H=.0005$, ANI AMEIEHT TEMF IS $3 G M$

1890 IF $L=L$ inin THEH $A 40$

1960 IS $=I \equiv t, 0(L-1)$

$1910 L 1=T h L=-1,1, L-1)<50$

$1920 \mathrm{Fl}=\mathrm{L} 1 \mathrm{MOD} 1$

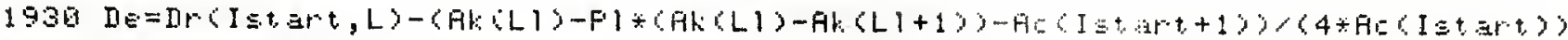

$1940 \mathrm{~K}=\mathrm{I} \equiv \mathrm{t}$ art

1950 Th(I $\equiv t a r t, J, L)=F H F(H a l d(L-1), T h(I s t a r t, J h e, L), T h(I \equiv t, a r t+1, J h e, L)$

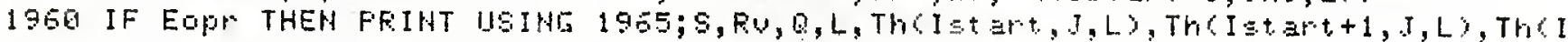
st. $3 r t+2, J, L), T h(I \leq t, a r t+3, J, L)$

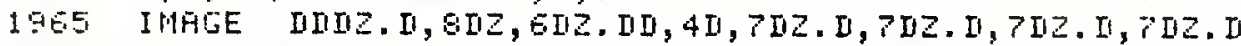

$197 \mathrm{G}$ GOTO HElPE.

1980 A4⿴囗S $S=S+D+(L)$

1990 IF Eread THEH A50

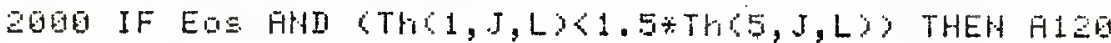

2010 A45: ThC1,J,L)=(2*Th(2,J,L)-Th(3,J,L)<2) 1,5

2020 EnEW $=\left\langle S_{i}\right\rangle=T$ desir $\rangle$

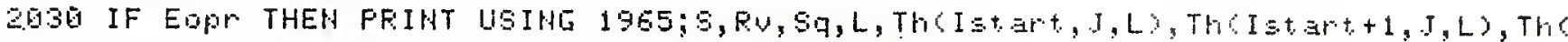
$I \equiv t a r+2, J, L), T h(I \equiv t, a r t+3, J, L)$

2640 LOTO HElPER

2045 H5口: $\quad M=1+1$

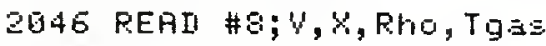

$2947 \quad X=X+x i$

2650 IF $V>1 E 49$ THEH $A 70$

2050 AEB: $\lg 3=0$

2079 If $x>x i n t$. THEH Vgas $=y *$ Kint $x$

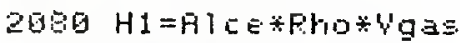

$2090 \quad Z=H 1 * H 2<(H 1+H 2)$

2100 LoEf $=2 \div S h / A C(1)$

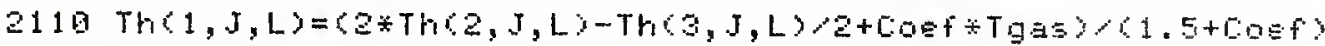

2111 fu=Z:(Tg.

2112 IF Eng THEH 2120

2113 IF $S>T$ TH

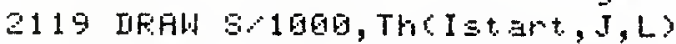

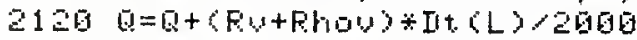

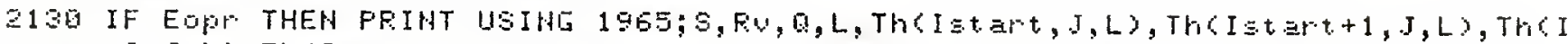
$\left.\equiv t a r^{r} t+2, J, L\right), T h\left(I \equiv t \equiv r^{r} t+3, I, L\right)$

2140 Fhou=Ru

2156 GOTO $H=1$ NER

21 EG A7G: IF Er THEH RBG

2170 Eresid=

2180 GOTO AEO

2190 ASE: $E_{r}=0$

2201 REM ----STEP SIZE IHEFEASE

$2210 \mathrm{Sh}=2 \div \mathrm{Sh}$

2220 A160:S=S-It:L

2230 Lni i $n=L$ i $m=\|_{n i}=L+1$

2240 I $j=I$ I $a(m)\rangle-1$

2250 J $\mathrm{j}=\mathrm{knO}(\mathrm{mm})$

2260 FDP $I=1$ TO $I i$

2270 Th(I, J $\left.j, M_{n}\right)=\operatorname{Th}(2 * I-1,4, M m-1)$

2275 HEXT I

2200 I $s t a\left(\|_{m i}\right)=1$

$2290 \quad K o s h=3$

2300 kount $=0$

$231010 T 02360$

2320 H120: IF J〈>I THEN $\mathrm{H} 45$

2330 Kount $=k$ ount +1

2340 Eow = (L SLhElp)

2350 DH Kount GOTO H45, H45, H100

23EG HElper:EOQ= (Lnin)=L)

$23>0 \quad I \equiv t a r t=I \equiv t a$ (L)

$2380 \quad I \equiv t .0 p=I \leqslant t o\{L)$

2390 Thax=mAx(Thax, Th(1, J, 1) 


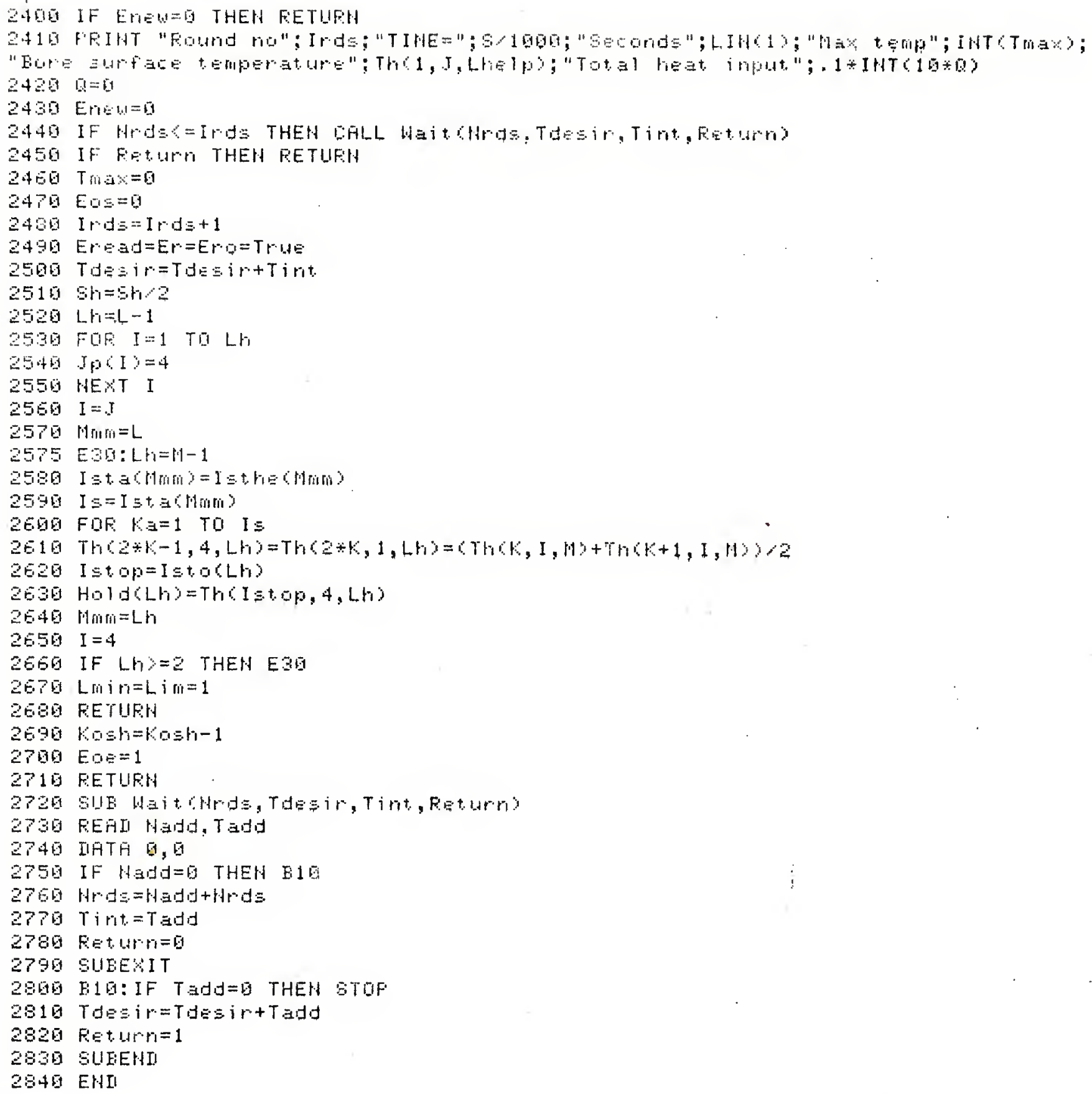




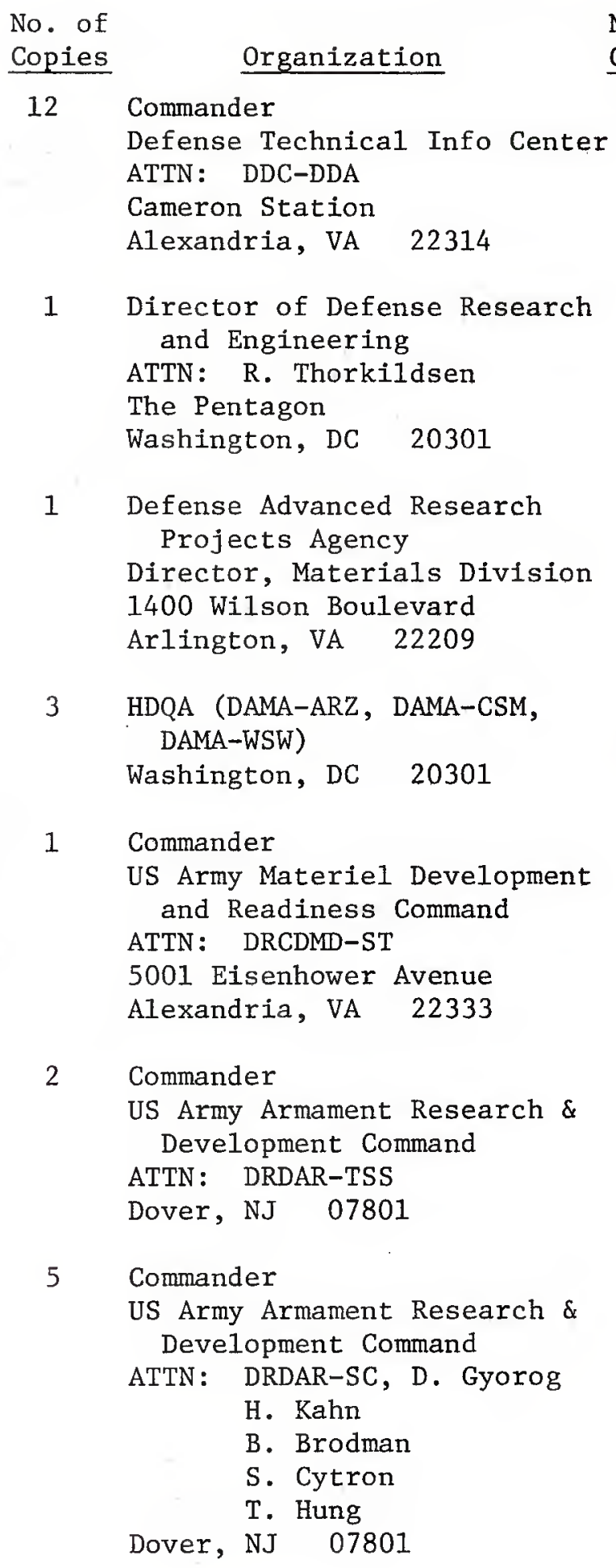

No. of

Copies

6 Commander

US Army Armament Research \& Development Command

ATTN : DRDAR-LC, J. Frasier

H. Fair

J. Lannon

A. Bracuti

A. Moss

R. Walker

Dover, NJ 07801

3 Commander

US Army Armament Research \& Development Command

ATTN: DRDAR-LC, R. Corn

E. Barrieres

K. Rubin

Dover, NJ 07801

2 Commander

US Army Armament Research \&

Development Command

ATTN: DRDAR-LC, D. Downs

K. Russe11

Dover, NJ 07801

1 Commander

US Army Armament Research \& Development Command

ATTN: DRDAR-QA, J, Rutkowski Dover, NJ 07801

1 Commander

US Army Armament Materiel

Readiness Command

ATTN: DRSAR-LEP-L, Tech Lib

Rock Island, IL 61299

3 Commander

US Army Armament Materiel

Readiness Command

ATTN : DRSAR-ASR

DRSAR-LEA

DRSAR-QAL

Rock Island, IL 61299 
DISTRIBUTION LIST

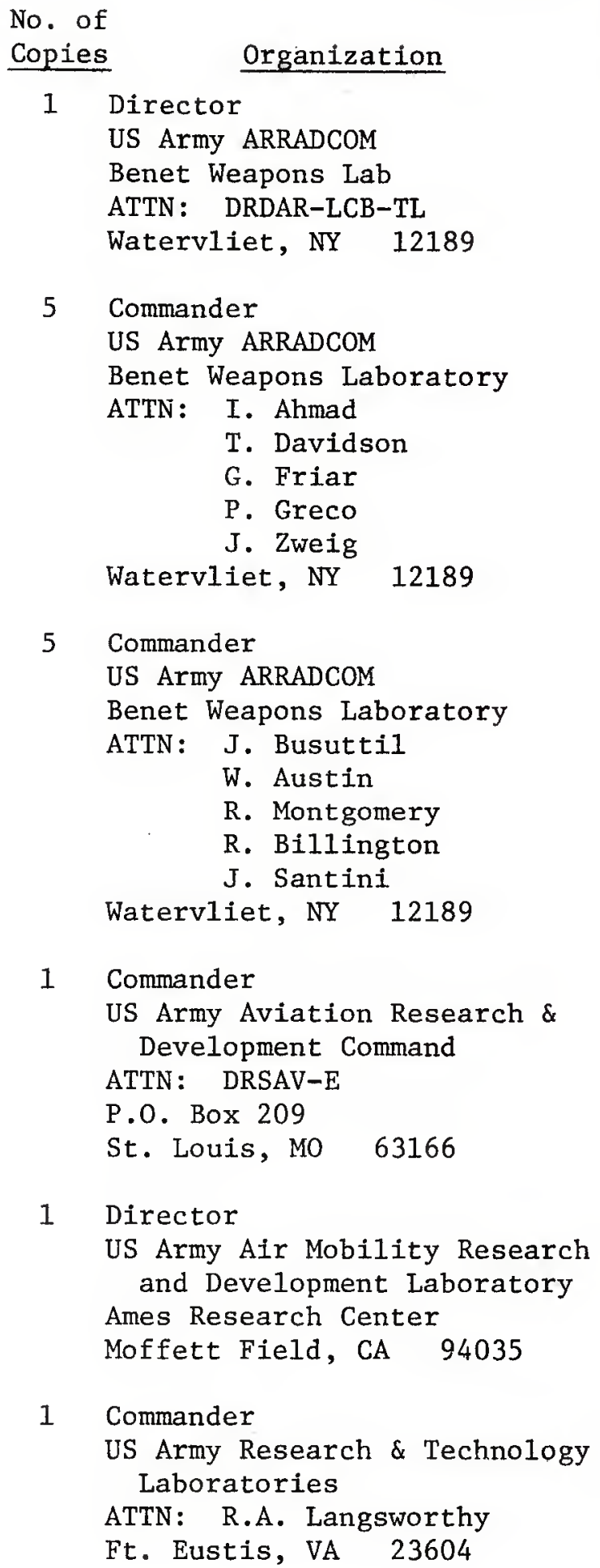

No. of
Copies

1 Commander

US Army Communications Rsch and Development Command

ATTN: DRDCO-PPA-SA

Ft. Monmouth, NJ 07703

1 Commander

US Army Electronics Research \& Development Command Technical Support Activity ATTN : DELSD-L

Ft. Monmouth, NJ 07703

1 Commander

US Army Missile Command ATTN : DRSMI-R

Redstone Arsenal, AL 35809

1 Commander

US Army Missile Command ATTN: DRSMI-YDL

Redstone Arsenal, AL 35809

1 Commander

US Army Tank Automotive Rsch and Development Command

ATTN: DRDTA-UL

Warren, MI 48090

1 Project Manager, M60 Tanks US Army Tank \& Automotive Cmd 28150 Dequindre Road

Warren, MI 48090

4 Project Manager

Cannon Artillery Wpns Systems

ATTN : DRCPM-CAWS

US Army ARRADCOM

Dover, NJ 07801

2 Project Manager - M110E2

ATTN: J. Turkeltaub

S. Smith

Rock Island, IL 61299 


\section{DISTRIBUTION LIST}

No. of

Copies

1 Project Manager - XMI Tank US Army Tank Automotive

Development Command 28150 Dequindre Road Warren, MI 48090

1. Project Manager Tank Main Armament ATTN: A. Albright Dover, NJ 07801

1 Project Manager, ARGADS Dover, NJ 07801

1 President US Army Armor \& Engineer Bd Ft. Knox, KY 40121

1 Commander US Army DARCOM Materie1 Readiness Support Activity Lexington, KY 40511

2 Director

US Army Materials \& Mechanics

Research Center

ATTN: J.W. Johnson

K. Shepard

Watertown, MA 02172

3 Director

US Army Research Office

ATTN: P. Parrish

E. Saibe1

D. Squire

P.O. Box 12211

Rsch Triangle Park, NC 27709

1 Director

US Army TRADOC Systems

Analysis Activity

ATTN: ATAA-SL, Tech Lib

White Sands Missile Range, NM 88002
No. of

Copies Organization

1 Commander

US Army Air Defense Center ATTN: ATSA-SM-L

Ft. B1iss, TX 79916

1 Commander

US Army Armor Center

ATTN : ATZK-XMI

Ft. Knox, KY 40121

1 Commander

US Army Field Artillery School

Ft. Sil1, OK 73503

5 Commander

Naval Surface Wpns Center

ATTN: M. Shamblen

J. O'Brasky

C. Smith

L. Russel1

T.W. Smith

Dahlgren, VA 22448

2 Commander

Naval Ordnance Station

ATTN : L. Dickinson

S. Mitchel1

Indian Head, MD 20640

1 Commander

Naval Ordnance Station, Louisville

ATTN: F. Blume

Louisville, KY 40202

2 AFATL (D. Uhrig, 0. Heiney)

Eg1in AFB, FL 32542

1 National Bureau of Standards Materials Division ATTN: A.W. Ruff

Washington, DC 20234 


\section{DISTRIBUTION LIST}

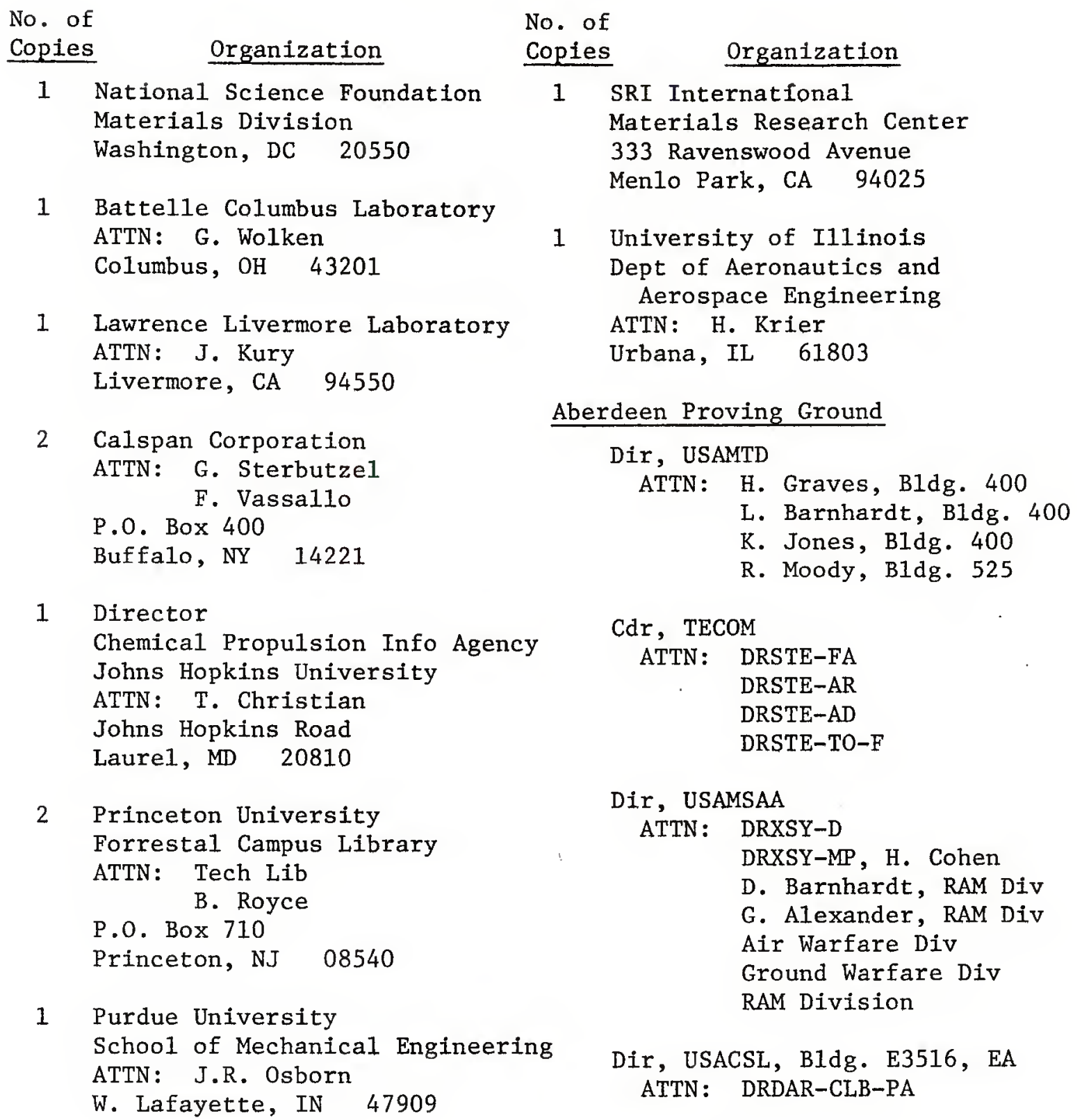


Please take a few minutes to answer the questions below; tear out this sheet, fold as indicated, staple or tape closed, and place in the mail. Your comments will provide us with information for improving future reports.

1. BRL Report Number

2. Does this report satisfy a need? (Comment on purpose, related project, or other area of interest for which report will be used.)

3. How, specifically, is the report being used? (Information source, design data or procedure, management procedure, source of ideas, etc.)

4. Has the information in this report led to any quantitative savings as far as man-hours/contract dollars saved, operating costs avoided, efficiencies achieved, etc.? If so, please elaborate.

5. General Comments (Indicate what you think should be changed to make this report and future reports of this type more responsive to your needs, more usable, improve readability, etc.)

6. If you would like to be contacted by the personnel who prepared this report to raise specific questions or discuss the topic, please fill in the following information.

Name:

Telephone Number:

Organization Address: 